\title{
UNA ICONOLOGÍA PUBLICADA EN MÉXICO \\ EN EL SIGLO XIX
}

FAUSTO RAMíREZ

\section{I}

El 14 de julio de 1865, el periódico El Cronista de México anunciaba en su sección de "Noticias sueltas" la inminente publicación de una obra "que trata de las alegorías y emblemas, y que se está traduciendo del francés". Por su tema, advertía el diario, la obra habría de ofrecer "un gran interés para todos los hombres estudiosos".

La impresión (continúa el artículo) se hará

en octavo mayor... Cada semana se publicará una entrega que irá acompañada de tres litografías ... Cada entrega de la iconología valdrá un real, precio sumamente barato si se atiende a lo útil de la publicación, a lo excelente de la edición, a lo rico del papel y a lo bien hecho de las litografías. La impresión se está haciendo en la imprenta situada en la calle del Puente de Jesús Nazareno. En ella, lo mismo que en la librería Madrileña, del portal del Águila de Oro; en la del señor Aguilar, calle de Santo Domingo núm. 5; en la alacena de D. Antonio de la Torre, y otros puntos de costumbre, está abierta la suscrición.

A lo largo de las siguientes semanas, con toda puntualidad, el mismo periódico fue informando de la aparición de sucesivas entregas, consig. nando el contenido de las estampas y encomiando brevemente la belleza de las imágenes, el esmero en la tipografía, la "limpieza en el tiro y corrección en el texto", la erudición de las notas, "de gran mérito y muy instructivas... con que el traductor mexicano ha enriquecido la obra".

Finalmente, el 13 de febrero de 1866, El Cronista de México advertia:

Se ha repartido la entrega 26 de esta curiosa obra, con la que acaba el tomo primero. Las litografías que tiene la expresada entrega son tres, que representan la Humanidad, la Humildad y el Invierno. En la semana próxima, según avisa el editor, se repartirá la carátula perteneciente al primer tomo, el discurso preliminar del traductor, Lic. $\mathbf{D}$. Luis G. Pastor, tres retratos y el indice de las materias que contiene el tomo. ${ }^{1}$

1 Los anuncios siguieron publicándose en la sección de "Noticias sueltas" del periódico mencionado, bajo el rubro de "Iconología". Tengo a la vista fotorreproducciones de los artículos correspondientes al 14 y 25 de julio, 1,9 y 30 de agosto, 4, 20 y 30 de septiembre, 3 y 19 de octubre, 5, 18 y 28 de diciembre de 1865 y 
El libro al que se referfan todas estas noticias ostenta en la portada el título siguiente: Iconologia o Tratado de Alegorias y Emblemas. Obra traducida al castellano y anotada por el licenciado don Luis G. Pastor, Catedrático de Literatura en el Colegio de S. Juan de Letrán. Tomo I. Y da, como pie de imprenta, la Imprenta Económica, Calle del Puente de Jesús Nazareno Número 7, México, 1866.

Esta obra se ha convertido en una verdadera rareza bibliográfica. Sólo conozco un ejemplar, llegado por un curioso azar a la biblioteca de este Instituto de Investigaciones Estéticas, donde se conserva en el acervo de libros raros. Nada insólito fue en el siglo xIx la publicación por entregas. Obras muy importantes se imprimieron de esta suerte, como por ejemplo los Trajes civiles, militares y religiosos de México, de Claudio Linati. De ahí el muy reducido número de ejemplares que han logrado conservarse de este género de publicaciones, pues, como lo señalara Manuel Toussaint, no todos los suscriptores solían encuadernar las entregas. ${ }^{2}$ Pero la rareza de esta Iconología se refiere también a otros aspectos, propios de la obra en sí.

En primer lugar, la cuestión de sus autores, no mencionados explícitamente en el título de la traducción. Luis $\mathbf{G}$. Pastor virtió al castellano los dos primeros tomos de la Iconologie par Figures ou Traité complet des Allégories, Emblèmes \& Ouvrage utile aux Artistes, aux Amateurs, et pouvant servir a l'éducation des jeunes personnes. Par MM. Gravelot et Cochin, obra publicada en París, chez Le Pau, en cuatro volúmenes en 12o, muy probablemente en $1796 .{ }^{3}$ Tan largo título, al parecer no deja lugar a dudas: se trataría de una empresa realizada por dos de los más célebres grabadores franceses del siglo xvıII, Hubert-François Bourguignon, llamado Gravelot (París, 1699-1773) y Charles-Nicolas Cochin, el joven (París, 1715-1790). Sin embargo, la historia de la obra es un poco más complicada.

13 de febrero de 1866. Agradezco a la maestra Esther Acevedo, del Seminario de Estudios de Historia del Arte, del Departamento de Investigaciones Históricas, INAH, el haberme facilitado esta información.

2 Manuel Toussaint lo afirma en el prólogo a la edición facsimilar de Trajes civiles, militares y religiosos de México (1828) de Claudio Linati, con introducción, estudio y traducción de Justino Fernández, México, UNAM, Instituto de Investigaciones Estéticas, 1956, p. 7.

3 El único ejemplar que he localizado en México del original en francés se halla en la Biblioteca José María Lafragua de la Universidad Autónoma de Puebla. La obra no ostenta fecha de publicación, pero le asignan el año de 1796 diversas fuentes bibliográficas, entre otras, el Dizionario sinottico di Iconologia, de Norma Cecchini, con introducción de Giuseppe Plessi, Bologna, Plessi Editore, 1976, p. xxr, nota 45. 
El origen de esta Iconología parece haber sido el Almanach iconologique, publicado a partir de 1764 e inicialmente firmado por Gravelot para ser continuado, a su muerte, por Cochin (1774-1780). ${ }^{4}$ Desafortunadamente, no he logrado consultar las láminas de este almanaque periódico, tal vez menos sistemático y definitivamente menos completo que el libro posterior que estamos comentando. Para hacer esta afirmación me baso en la "Advertencia del editor" que aparece en la edición francesa de la Iconologie y que Pastor, inexplicablemente, no incluyó en su traducción. A continuación transcribo íntegro el texto de esta advertencia, porque contribuye a aclarar la génesis o paternidad de la obra original:

La publicación de esta obra, impresa en 1791 al viejo estilo, se ha visto retardada por la muerte del artista que concibió el proyecto. $\mathrm{Su}$ ejecución fue confiada inicialmente a Gravelot, cuyo mérito y reputación aseguraban buen suceso. Cochin, a la muerte de Gravelot, se encargó de continuar Ia Iconología; el solo nombre de Cochin basta para suscitar en la mente de los amantes del arte la imagen de un artista famoso, que supo aliar al gusto y al genio todos los conocimientos referentes a su arte, y cuya memoria perdurará gratamente en la memoria de quienes le conocieran.

Cochin advirtió que el plan adoptado por Gravelot no tenía la extensión ni el desarrollo indispensables en un tratado de Iconología y habiase propuesto refundir por completo el texto de la obra. Un artista connotado por su talento y por sus conocimientos literarios, el ciudadano Gaucher, ha tenido a bien encargarse de este empeño y añadir gran número de artículos que con seguridad no habrían escapado a la sagacidad de Cochin.

$\mathrm{Y}$ pues muchas figuras guardan entre sí relaciones necesarias, o bien préstanse sus a tributos auxilios recíprocos, se ha creído indispensable reunirlas en una misma estampa; sin embargo, al calce sólo figura el nombre de la figura principal. EI índice general, colocado al final del último tomo, indicará el artículo a consultar; cada volumen incluye además sus índice respectivos.

En un tratado de Iconología las figuras no constituyen algo accesorio, sino la parte esencial. Basta citar, entre los nombres de los artistas encargados de realizarlas, los de Aliamet, Saint Aubin, Choffard, Lemire, Delaunai, Massard, para quedar persuadido que nada se ha escatimado de aquello que pueda contribuir a hacer esta obra digna de la buiena acogida de artistas, amantes del arte y público esclarecido. 5

4 El dato aparece consignado en la entrada correspondiente de la copiosa nómina bibliográfica de libros emblemáticos y alegóricos recogida por Mario Praz en sus Studies in Seventeenth-century imagery, 2a ed., Roma, Edizioni di Storia e Letteratura, 1964 .

5 Gravelot y Cochin, Iconologie par figures .., t. 1, pp. II-IV. 
Como se desprende de lo anterior, la colaboración del grabador Charles Étienne Gaucher (París, 1740-1804) fue también muy importante, tanto por lo que toca a la preparación definitiva del texto, ${ }^{6}$ como a la composición de las estampas, en que se reúnen diversas alegorías, dis" posición peculiar -aunque no exclusiva- $\tau$ de esta iconología y que constituye una de las diferencias más evidentes respecto de su modelo indiscutible, la Iconologia de Cesare Ripa Perugino.

Otro aspecto que llama la atención en la Iconologie par figures es la fecha relativamente tardia, y aun en ciento modo extemporánea, de su publicación: 1796, la edición en francés; 1865-1866, su traducción al castellano. Mas es necesario justificar estos calificativos mediante algunas consideraciones históricas.

La Iconologia de Gravelot y Cochin, al igual que otros tratados semejantes publicados a fines del siglo xvin y durante la primera mitad del siglo $\mathrm{xIx},{ }^{8}$ derivan en última instancia de la obra de Cesare Ripa, impresa por vez primera el año de 1593 en Roma y vuelta a editar en repetidas ocasiones, con adiciones crecientes y profusamente ilustrada. ${ }^{9}$

$6 \mathrm{El}$ Larousse du XXe. siècle atribuye a Gaucher la Iconologia en la entrada correspondiente a dicho artita: "II a laissé une Iconologie ou traité complet des allégories, des emblèmes, ouvrage auquel Nicolas Cochin avait mis la main avant de mourix (1796)." t. 3, p. 729.

7 La reunión de varias alegorias en una sola estampa se encuentra también en la Iconologia de Filippo Pistrucci, de la que damos fieha completa en la nota 8.

8 Mencionemos los siguientes tratados iconológicos tal dios: Dictionnaire iconologique de Honoré Lacombe de Prezel, 2 vols., París, 1756, citado por Gravelot y Cochin como una de las fuentes para su tratado. Iconologie tirée des divers auteurs, de Jean. Baptiste Boudard, 3 t., Parma, 1759. Los dos volúmenes de la Iconology de George Richardson, Londres, 1777-1778-79. Le Trésor des artïstes et des amateurs des arts ou la Guide des peintres, sculpieurs, graveurs, architectes, décorateurs, etc., dans le choix des sujets allégoriques ou emblematiques qu'ils sont à employer dans ses compositions. 3 vols., París, 1810. Iconologia, ovvero immagini di tutte le cose principali a cui l'umano ha finto un corpo, de Filippo Pistrucci, 2 vols., Milán, 1819-21 (edición bilingüe, con traducción francés). Iconology or Emblematic figures explained... de William Pinnock Londres, I830.

9 Para este estudio he utilizado dos ediciones del libro de Ripa, la de Padua, 1611, editada por Pietro Paolo Tozzi, en la edición facsimilar publicada por Garland Publishing Inc, Nueva York, 1975. Y la edición veneciana de 1645, cuyo largo título dice asi: Iconologia di Cesare Ripa Perugino . " divise in tre libri ne quali si esprimono varie imagini di virtù, vitii, affeti, passioni humane, arti, discipline, humori, elementi, corpi celesti, provincie d'Italia, fiumi, etc... e altre materie infinite utili ad ogni 
Se debe al libro de Ripa el sentido que se dio al término iconologia durante los siglos xvir, xviI y xix. Ripa se refiere, en el "Proemio" de su obra, a "las imágenes hechas para significar una cosa diversa de aquella que se ve con los ojos", imágenes salidas de "la imitación de los vestigios que se encuentran en los libros, medallas y mármoles tallados por la industria de latinos y griegos, o bien por aquellos otros más antiguos que fueron los inventores de este artificio", y cuya descripción y explicación forman el asunto de su obra.

El impresor de la edición veneciana de 1645 , al instruir a sus lectores acerca "Del origen y desarrollo de la Iconología", afirma que iconología quiere decir "razonamiento de las imágenes, porque en ella se describen infinidad de figuras explicadas con prudentes y doctos discursos, mediante los cuales se representan la belleza de las virtudes y la fealdad de los vicios, a fin de huir de éstos y abrazar aquéllas". Y añade: esta obra "surgió del noble pensamiento del Caballero Ripa, que con aplicación extremada se empeñó en acopiar figuras de los egipcios, griegos y latinos y en concebir otras de su propia invención, instando a letrados amigos suyos a obsequiarnos de consuno con nuevas formas de imágenes revestidas de símbolos místicos". ${ }^{10}$

Bastan estas citas para entender que la iconología, en su antigua acepción, se ocupa en la invención y desciframiento de las imágenes alegóricas, mediante las cuales se hacen sensibles conceptos abstractos de índole moral, afectos, pasiones y experiencias humanas, asi como situaciones relativas al contorno del hombre, sea el que le ofrece la naturaleza, sea el ámbito cultural que él mismo se ha forjado. El repertorio iconológico incluye por ello personificaciones de los ciclos temporales (estaciones, meses) y de la ubicación geográfica (continentes, ríos, provincias), así como formas de gobierno, ciencias, ocupaciones, etcétera. De todo esto era posible (y deseable) deducir una lección provechosa, como claramente lo dejara asentado el impresor y lo llevara a cabo el propio Ripa.

stato di persone. Ampliata del sig. Cav. Giovanni Zaratino Castellini Romano... In Venetia, presso Cristoforo Tomasini, MDCXLV.

La bella edición de Hertel, 1758-60, publicada en Augsburgo con ilustraciones de Gottfried Eichler el joven (y asequible en una edición modema publicada por Dover Publications, N. York, 1971 con el título de Baroque and Rococo Pictorial Imagerry. de Cesare Ripa) no sirve para un propósito comparativo como el nuestro por carecer de textos.

10 Cito por la edición de Venecia, 1645. 
El elemento pedagógico es de hecho uno de los componentes fundamentales de la ciencia de las imágenes practicada por Ripa. Y esto en más de un sentido: el procedimiento de acumular características y atributos en una figura, para expresar las cualidades que se suponen esenciales de un concepto, provenía de prácticas mnemotécnicas usuales en la Edad Media. Solían los eruditos medievales imaginar figuras complejas que resumian las diferentes características de un vicio o virtud, a fin de facilitar (gracias a su extraño aspecto) el discurso de sus exposiciones con fines instructivos y morales. ${ }^{11}$

Hay aquí un doble proceso del que se sirvió Ripa: por un lado, la invención acumulativa que da origen a figuras heterogéneas; por el otro, la descripción puntualizada de los elementos que integran dichas figuras, con una finalidad didáctica. El resultado lógico de esta técnica acumulativa es la configuración de híbridos monstruosos, de aspecto repugnante y enigmático a la par, muy alejados de la morfología clásica que Ripa reclamaba como su fuente primordial de inspiración.

A pesar de todo, es innegable que la obra de Ripa debe mucho a la tradición clásica. En primer lugar, la idea misma de la personificación de conceptos abstractos en términos antropomórficos es un fenómeno propio de la cultura grecorromana, propiciada por la misma estructura del lenguaje: en griego y en latín, los conceptos abstractos son generalmente de género femenino, lo que permite concebirlos a la vez bajo formas femeninas. ${ }^{12}$ Por otra parte, en su interés por preservar los valores de sus relatos mitológicos frente a los embates racionalistas de los filósofos, ya los griegos del siglo vi a. C. dieron con un expediente brillante: la interpretación alegórica. Dioses y héroes personifican en realidad profundas verdades acerca de la naturaleza y la condición humana; incluso sus acciones más reprobables encuentran justificación mediante la explicación alegórica, exquisito juego intelectual reservado a los eruditos. Posteriores asedios ayudaxán a consolidar esta tradición en el helenismo y, luego, en la antigüedad tardía, cuando la concepción cristiana amenace con la aniquilación de las antiguas deidades. Era ya tan fuerte esta tradición, empero, que el propio cristianismo heredará y adoptará el alegorismo, y los dioses paganos pervivirán a

11 Consúltese el importante ensayo de Ernst H. Gombrich "Icones Symbolicae. Philosophies of symbolism and their bearing on art", incluido en su libro Symbolic Images. Studies in the art of the renaissance II, $2^{\text {a }}$ ed., Londres, Phaidon, 1978. Sobre la tradición didáctica, cf. pp. 130-145.

12 Cf. Gombrich, ibid, 125 . 
lo largo de la Edad Media mediante la interpretación astronómica, histórica o alegórico-moral. ${ }^{13} \mathrm{Al}$ mismo tiempo, los humanistas cristianos, de Prudencio y Boecio al Dante, crearán nuevas personificaciones de abstracciones morales en sus epopeyas filosófico-teológicas.

Con el Renacimiento y, más aún, con el manierismo, la vieja tradición mitográfica se expande y sistematiza en las obras de algunos humanistas como Natale Conti (1551) y Vincenzo Cartari (1556), ${ }^{14}$ unas cuantas décadas antes de que Ripa codifique a su vez la práctica de la imagen emblemática. De hecho, mito y alegoría formaron una unidad expresiva inextricable y llegaron a vertebrar el código de entendimiento de la cultura dominante.

Pero sigamos analizando lo que debe Ripa a la tradición clásica. Sin duda, una porción sustancial de sus alegorías se fundamenta en el concepto de analogía derivado de la teoría aristotélica de la metáfora. ${ }^{15}$ Es decir, las peculiaridades distintivas de las personificaciones funcionan a modo de comparación entre cualidades afines; así, por ejemplo, es válido asociar la firmeza que sugiere una columna enhiesta con la idea de la constancia, o la fiereza del león con la impetuosidad que se atribuía al temperamento colérico. Este tipo de analogías produce por lo general imágenes claras, fáciles de interpretar en cuanto se descubre la cualidad intrínseca que opera de enlace asociativo.

Hay, sin embargo, otro grupo menor de figuras que derivan de un concepto diferente de la imagen simbólica: el de la tradición hermética, estudiada con ahinco y unción, durante el Renacimiento y todavía en el barroco, en la cábala o en fuentes de supuesto origen egipcio -como el célebre estudio sobre la jer oglífica atribuido a Horapollo Niliacus (manuscrito encontrado en 1419 y publicado por vez primera en 1505) y confirmada en las elucubraciones de neoplatónicos antiguos y modernos.

Conforme a esta tradición, una imagen simbólica constituye un jeroglifico, una especie de cifra en que se concentra a tal punto la "esencia" del concepto representado que su contemplación puede llegar a provocar, en una suerte de adivinación extática que supera la reflexión meramente racional, el atisbo de la idea originaria (la Idea) en toda

$13 \mathrm{Cf}$. Jean Seznec The survival of the pagan gods. The mythological tradition and: its place in renaissance humanism and ast. Pxinceton University Pxess, 1972. Y Mysteriously meant. The rediscovery of pagan symbolism and allegorical interpretation in the renaissance, de Don Cameron Allen, Baltimore, The John Hopkins Press, 1970.

14 Cf. Seznec, loc cit., en especial el libro II, capítulo I.

15 Gombrich, op. cit: 142-144, y sobre la tradición platónica en la imaginería simbólica, 145 ss 
su pureza. Ejemplo típico es la imagen de la serpiente que se devora a sí misma, símbolo dual del Tiempo y de la Eternidad, a la que los herméticos atribuían una potencia o irradiación intrínseca casi sobrenatural. Por supuesto, sólo los iniciados lograban penetrar el misterio de estos símbolos, que acaso parecieran corrientes o triviales a los no enterados.

Algo de esta tradición impregna parcialmente la imaginería de Ripa, como se desprende de las referencias a los egipcios y de aquel revestimiento de las imágenes con "símbolos místicos" al que alude su editor veneciano.

En la Iconologia de Ripa se resumen, convergen y conviven, pues, diversos conceptos de la imagen simbólica y la interpretación alegórica. Es, además, el primer texto en que se codifican sistemáticamente estas imágenes en sus componentes fundamentales, facilitando su desciframiento merced a la ordenación alfabética de las mismas, a la manera de un diccionario que habria de fungir como repertorio de indispensable referencia a sucesivas generaciones durante largo tiempo. De ahí la frecuencia de sus ediciones, traducciones y adaptaciones en el siglo XvII y la primera mitad del xvirI.

¿Cómo no iba a encontrar este código simbológico entusiasta acogida en una cultura radicalmente emblemática, como lo fue la de la época barroca, que veía al mundo como un inmenso y variado "jeroglífico" de Dios y se complacía en establecer constantes correspondencias entre macro y microcosmos, cosmos presidido y penetrado en todas sus partes por la divinidad y las presencias sobrenaturales?

La Iconologia de Ripa pertenece natural, consustancialmente a esta cosmovisión teocéntrica y providencialista. Mas por la misma razón el libro se veía condenado a pender plena vigencia en cuanto los presupuestos culturales en que se fundaba fueran socavados por otro concepto del mundo. Eso iba a ocurrir a mediados del siglo xvin, cuando el racionalismo ilustrado y el espíritu científico se esforzaron por erradicar los misticismos recónditos, al tiempo que emprendian la exploración de un universo obediente a la inflexible cadena causal de leyes observables y mensurables. Las viejas mitologias empezaron a perder autoridad moral frente a los hechos ejemplares que la historia antigua ofrecía para edificación del honnête homme ilustrado, que comenzó a poner en tela de juicio los fundamentos mismos de la organización social vigente y a pensar nuevas posibilidades de gobierno.

El ciudadano de futuras repúblicas demostraba ya un interés mayor en 
la virtuosa actitud de Horacio, de Régulo o de Marco Bruto que en los amoríos de Júpiter o de Apolo. Pronto, los cambios radicales operados por las revoluciones modernas exigirían la representación de los hechos históricos contemporáneos sin el distanciamiento enaltecedor de la parafernalia mitológico-alegórica con que el barroco acostumbraba revestir las acciones de los príncipes.

E1 resquebrajamiento del prestigio de que gozara la mitología como sustento de la expresión artística durante el antiguo régimen, coincidió y no por casualidad, con una actitud simultánea de crítica y rechazo cada vez mayor del mundo de las alegorías. Primero fue desencanto ante la supuesta profundidad de los contenidos que se intentaba comunicar bajo el velo de la alegoría, como lo demuestra la frustración que expresara el Abate Pluche (1748):

¿Quién se toma el trabajo de leer, en las pinturas alegóricas del señor Le Brun y de muchos otros, lo que los artistas se hayan propuesto significar? Todas estas figuras enigmáticas lastran lo que debería divertirme o instruirme... Puesto que el único objeto de una pintura es mostrar aquello que no puede expresarse en palabras, resulta ridículo tener que esforzarse en comprenderla... Y, de ordinario, cuando por fin logro adivinar lo que estas figuras significan, resulta que aquello, en sustancia, apenas merecía la pena de un encubrimiento tan elaborado. ${ }^{16}$

Luego, creciente impaciencia e incapacidad para descifrar los códigos. En su Ensayo sobre la pintura, Diderot confesaba:

No puedo sufrir... la mezcla de seres alegóricos y reales. Veo temblar, con esta afirmación, a todos los admiradores de Rubens... La mezcla de seres alegóricos y teales da a la historia un aire de cuento; ... este defecto desfigura, en mi opinión, la mayoría de las composiciones de Rubens. No las entiendo. ¿Qué significa esa figura con un nido de pájaros en las manos, qué hacen Mercurio, el arcoiris, el zodíaco, el sagitario en una habitación y en torno al lecho de una parturienta? Haria falta hacer salir de la boca de cada uno de estos personajes una leyenda que explique lo que se proponen, tal y como se ve en nuestras antiguas tapicerías palaciegas. ${ }^{17}$

Finalmente, ignorancia y total indiferencia ante el alegorismo. Es típica la actitud de Hipólito Taine, un siglo después, al comentar un

16 Pluche, Histoire du ciel, II, 427, cit. en Seznec, op. cit., p. 273, nota 50.

17 Diderot se refiere en este pasaje a la representación de El Nacimiento de Luis XIII, del ciclo rubeniano de la Vida de Maria de Médicis, Se halla en el capítulo $\mathrm{v}$ del Essai sur la peinture de Diderot (diversas ediciones). 
cuadro del Veronés en su Viaje a Italia (1866) : "Se trata de una alegoría, pero el asunto apenas nos concierne." 18

La generalización de semejante actitud dio por resultado que la Iconología de Ripa fuese cayendo en un olvido paulatino, ${ }^{19}$ a tal grado que para Emile Mâle fue todo un descubrimiento el toparse -en el transcurso de su investigación acerca del arte religioso después del Concilio de Trento, iniciada en 1922- con el libro de Ripa, que vino a confirmar su sospecha de que existiera un texto codificador que explicara las semejanzas que percibía entre las imágenes emblemáticas usadas por diferentes artistas en el siglo xvı. ${ }^{20}$ Así de profundamente olvidado de los historiadores de arte había quedado el otrora célebre tratado de Ripa. ${ }^{21}$

18 Voyage en Italie (1866), Ir: 466. Cit. en Seznec, op. cit: $\mathrm{p}_{\mathrm{n}} 6$, nota 7.

19 "Ripa's Fate", de D. J. Gordon, fue una conferencia importante sobre el desprestigio creciente (y el consecuente olvido) sufrido por la iconología de Ripa ya en el siglo xvII, $\mathrm{y}$ algunas razones de este fenómeno. La conferencia fue recogida en volumen en The Renaissance Imagination. Essays and Lectures by $D$. J Gordon. Collected and Edited by Stephen Orgel. Berkeley, University of California Press, 1980, pp. 51-74.

Este libro llegó a mis manos después de que había redactado este artículo en su forma original. Creo oportuno mencionar algunas observaciones hechas por Gordon. Según este investigador, el primer texto en que se tacha de oscuro, donfuso, afectado e impropio el alegorismo derivado de Ripa, fueron las Reflexiones criticas sobre la poesia y la pintura (1719) del Abate Jean-Baptiste du Bos, quien dirigió sus ataques principalmente contra el ciclo de pinturas de la Vida de Maria de Médicis, de Rubens, y contra las decoraciones del paladio de Versalles, de Le Brun.

Más o menos por los mismos años, Joseph Addison, en Inglaterra, censuraba igualmente los significalos abstrusos que los mitógrafos antiguos y modernos solían dar a las imágenes clásicas, y abogaba por una interpretación clara, sencilla y natural basada en el sentido común.

Se instaura así una doble corriente de censura del pensamiento emblemático o alegorizante, particularmente en sus aspectos más abstrusos; y del arte de lo que para estos escritores constituia su pasado inmediato: la época barroca.

Ya en 1747, otro escritor inglés, Joseph Spence (quien en nombre de la supuesta "pureza" y "simplicidad" de las obras de los antiguos abominaba de las imágenes compuestas y "monstruosas" popularizadas por los mitógıafos y emblematistas) se negará a usar los "absurdos" emblemas de Ripa -cuyo texto conocía perfectamentepara descifrar las alegorías batrocas. Es evidente que semejante negativa, al generalizarse en años posteriores, quitó toda vigencia como clave interpretativa al libro de Ripa, lo que explica que haya caido en un olvido casi completo.

20 Emile Mâle, L'Art Réligieux de la fin du XVI siècle, du XVII siècle et du XVIIL siècle. Etude sur l'Iconographie après le Concile de Trente, $3^{a}$ ed., Paris, Librairie Armand Colin, 197:2, pp. 383 ss.

21. Gordon puntualiza que, antes de Mâle, ya algunos investigadores habían utili. zado aislada y ocasionalmente el libro de Ripa (por ejemplo, Paul Reyher y Erwin Panofsky); pero fue a partir de la divulgación de los trabajos de Mâle en 1927 cuando 
Este olvido se relaciona intimamente con el proceso de cambio que experimentó el arte o, más bien, la noción que se formaron artistas y conoisseurs del siglo xvin acerca de los propósitos del arte.

Ya el rococó había opuesto un arte de levedad exquisita y placentera a las complejas estructuras visuales renacentistas y barrocas, que exigían un laborioso proceso de reflexión, desciframiento y verbalización de los contenidos.

Tal vez podamos tachar de frívola la censura que hacía el abate Pluche a los pintores que demandaban del espectador esfuerzos de exégesis que, en su opinión, no le corresponden. Pero esta censura entrañaba posibilidades revolucionarias. Con la distinción propuesta por el Earl de Shaftesbury y John Addison entre leer y ver un cuadro (y la simpatía de ambos por la segunda opción) se inició un género de reflexión estética que tendería a disminuir la importancia del contenido en favor de los valores puramente visuales, El camino abierto por esta apreciación esteticista de la obra habría de desembocar (mediando muchos otros factores) en el formalismo de una parte sustancial del arte de nuestro siglo. ${ }^{22}$

Por otra parte, el afán de autoexpresión del artista y la concepción subjetivista del arte, característicos del romanticismo (un fenómeno que tiene también, no lo olvidemos, su arranque y primer desarrollo en la segunda mitad del siglo xviII) tendieron a restarle significatividad a un alegorismo rígidamente codificado como el que prevaleció hasta entonces.

A medida que se desplegaban y fortificaban las tendencias románticas, la obra de arte se fue poblando de simbologías cada vez más personales y aun herméticas (como lo demuestran Blake, Goya, Runge o Friedrich).

Coincido, pues, con Ronald Paulson, en la idea de que el siglo xvir fue la etapa crucial en el proceso de crisis de la iconografía tadicional (ligada con el emblematismo) y el despegue de un complicado proceso de búsqueda y desarrollo de nuevas estructuras de significado. ${ }^{23}$ En este sentido (y para volver a mi afirmación previa), la publicación a fines del siglo xviri de una iconología tradicional como la de Gravelot y

se generalizó haciéndose obligada la referencia a Ripa, entre los estudiosos del arte renacentista $(o p, c i t, 54)$

$22 \mathrm{Cf}$. Emblem and Expression. Meaning in english art of the eigteenth century, de Ronald Paulson. Cambridge, Harvard University Press, 1975, p. 9.

23 Ibid. 
Cochin, resultaba tardía y relativamente extemporánea. Sin embargo, el proceso histórico del arte nunca es unidireccional y en una misma época conviven tantas posibilidades estilísticas cuantos grupos sociales requieran expresar su "ideología en imágenes". Esto, que en principio es válido en todos los tiempos, es particularmente cierto para un periodo tan complejo como lo fue el inicio de la edad moderna.

En los párrafos anteriores he pergeñado esquemáticamente algunas de las concepciones artísticas que despuntan al promediar el siglo xviII. Pero no todos los grupos productores de arte coincidieron con estas posiciones estéticas, propias más bien de artistas y núcleos minoritarios, antiacadémicos y de avanzada.

Conviene recordar que el siglo xvir fue también la época en que proliferan y se consolidan las instituciones académicas, extendiéndose hasta abarcar todo el ámbito occidental, de Rusia a América. Las academias de arte van a constituir el último reducto de la tradición humanista y alegórica, puesta ahora al servicio de los nuevos grupos sociales que acceden al poder con las revoluciones modernas y en el transcurso del siglo XIX.

Tanto el libro de Ripa como, en particular, las iconologías escritas y publicadas en la última parte del xviri y a principios del xIx, con el fin de superar los supuestos defectos del primero, tuvieron, pues, un cometido que cumplir en el ámbito de la institución académica. No es casual que en una lista de los libros que, para 1785, obraban en la biblioteca de la recién fundada Academia de San Carlos de la Nueva España figura el Ripa, así como un ejemplar de "Las transformaciones de Ovidio en castellano". ${ }^{24}$

Ahora bien, los tratados iconológicos postreros evidencian sin lugar a dudas el impacto de las ideas ilustradas y la necesidad que experimentaron los iconólogos de plegarse al tenor de los tiempos nuevos, como lo demuestra ejemplarmente la Iconologia de Gravelot y Cochin.

\section{III}

E1 "Discurso preliminar" del libro es muy significativo. Los autores definen la iconología, a la vieja manera, como la ciencia que, mediante

24 Eduardo Báez Macias, Fundación e historia de la Academia de San Carlos, México, Colección Popular Ciudad de México, 1974, p. 109. 
el estudio de "los atributos y emblemas inventados por los artistas y consagrados por el uso", hace posible "la inteligencia de la alegoría"; ciencia que "debe ser en cierto modo el código de los artistas de todo género".

El primer párrafo del Discurso revela a las claras la afinidad de los autores con las doctrinas académicas en boga:

En la poesía, en la pintura, en todas las artes que hablan a la imaginación, y cuyo objeto es instruir y agradar, la moral no ofrece a los hombres preceptos útiles y verdades consoladoras sino ocultas bajo el velo del misterio; la historia misma no se sirve de otro lenguaje que del de la alegoria para conservar la memoria de un acontecimiento, consagrar un hecho heroico o inmortalizar la memoria de una acción generosa (los subrayados son míos).

No vacilan los autores en calificar de bella creación del entendimiento humano a la alegoría, amparándose bajo la autoridad de Homero, quien en cierto sentido, dicen, "podría ser considerado como el creador de la alegoría".

Hasta aquí, el texto no se ha salido del cauce de la tradición. Mas pronto Gravelot y Cochin dan muestra de una nueva actitud al rastrear críticamente la historia de la práctica alegórica moderna con el propósito de poder evitar "los errores en que han incurrido la mayor parte (de los autores que han escrito sobre esta materia), según la falsa idea que se habían formado de la alegoría". Se refieren pues, brevemente, a las obras emblemáticas de Piero Valeriano, Andrea Alciati y Cesare Ripa. El mismo hecho de enjuiciar mediante el raciocinio a estas autoridades, hasta entonces indiscutibles, manifiesta en sí una deuda con el pensamiento ilustrado.

Dentro de este espíritu, los autores examinan la obra de sus predecesores y se apresuran a señalar aquello que conceptúan como un error inaceptable en la práctica de la alegoría: su confusión con el jeroglifico. El jeroglífico constituye un "enigma oscuro, fatigoso", en tanto lenguaje cifrado reservado a iniciados; la alegoría, por el contrario, pretende ser un lenguaje universal accesible "a todas las naciones", y como tal debe ser claro, expresivo y elocuente.

En la medida en que Ripa olvidó esta verdad, inspirándose en los autores que perpetuaban la tradición de la escritura jeroglífica, incurrió en una equivocación lamentable de la que, según afirman nuestros iconólogos, podía haberlo sustraído el ejemplo de las felices y claras 
invenciones de la antigüedad grecorromana así como el de los modernos que han enriquecido el lenguaje alegórico.

Así pues, los parámetros o correctivos que se fijan los autores de esta nueva Iconologia, a fin de no incurrir en el error, son: la consulta de las fuentes fecundas de la antigüedad y de los poetas y pintores más célebres, "pero siempre con discernimiento"; y la lectura crítica de los autores de iconologías anteriores, aprovechando "las luces".

Los textos en que se describen y explican las imágenes de la Iconologie par figures se caracterizan por su brevedad, y esto contrasta radicalmente con el libro de Ripa, especialmente en sus ediciones de mediados del siglo xvir, como la veneciana de 1645, en la cual el comentarista acumuló cita tras cita, dentro de esa actitud peculiarmente barroca de apoyarse en las autoridades para mejor avalar un argumento. Semejante "erudición de acarreo" desaparece totalmente de la Iconología de Gravelot y Cochin, y esto por la premisa ilustrada de repudiar el aborrecido "principio de autoridad": ahora la razón y la ciencia, basadas en la experiencia empírica, deberían de fundamentar las propias afirmaciones. El "sentodo común" de los ilustrados se imponía así sobre la antigua "sabiduría recóndita" tan apreciada por renacentistas y barrocos.

Nuevas disciplinas hacen su aparición en el repertorio iconológico sustituyendo a otras que han caido en el desprestigio. Así, la Astronomia desplaza a la Astrologia. Aparece la Quimica. ${ }^{25}$

Instrumentos nuevos se añaden o reemplazan a los antiguos como atributo de las ciencias. Por ejemplo, en la personificación de la Arit-. mética "se han añadido también (advierten los autores) los cuadrados de que hacía uso para sus cálculos el famoso Anderson"; y vemos la figura que representa a la Fisica atareada en un experimento con la máquina neumática y rodeada de otros mecanismos novedosos, como "la máquina eléctrica y la de Papin". A la Ciencia se la representa en figura de matrona, de pie "sobre el libro en que se recogen los conocimientos humanos (la enciclopedia) y se desarrollan sus enlaces y relaciones".

Las formas de vida de la modernidad hacen, pues, su entrada en una convivencia un tanto tensa con el mundo de imágenes de aspecto intemporal propio del clasicismo. Los autores tratan de soslayar, en lo posible,

25 En este caso, y en muchos a los más que voy a referix en las páginas siguientes, estoy citando por la edición francesa de la Iconologie par figures, ya que no aparecen en la edición mexicana por no corresponderles todavía el orden alfabético respectivo. 
el escollo del "neologismo, o abuso de nuevos emblemas", al que encuen. tran tan peligroso como el de la monstruosidad, otro de los puntos álgidos en que los modernos iconologistas manifestaron su total desacuerdo con Ripa. Dicen al respecto Gravelot y Cochin:

"Aunque Ripa ostenta lujo de erudición, carece de gusto; y para convencerse de ello, basta dirigir una rápida ojeada sobre esa multitud de figuras monstruosas que deben proscribirse en la pintura", y que, no obstante, gustaban al italiano. Y citan, como ejemplo, las siguientes figuras de Ripa: Eternidad, Engaño, Fraude, Glotoneria, Prudencia, Concordia Invencible y Teologia.

Para entender mejor cuál es el objeto de discusión y calibrar así la eficacia de los expedientes usados por Gravelot y Cochin para salvar el escollo al que aluden, resulta conveniente referirnos brevemente a los principios fundamentales de lo que Giuseppe Plessi ha llamado acertadamente "gramática iconológica":

El elemento fundamental de la composición iconológica es una figura (a veces dos, rara vez un grupo de tres figuras), por lo general humana y femenina. Es insólito personificar conceptos en figura animal o de algún otro reino de la naturaleza. A fin de dotar a la figura de peculiaridad significante, se le confieren determinados "signos distintivos convencionales, llamados atributos, que afectan a la figura en sí o que se representan sobre o junto con ella". ${ }^{26}$

Las categorías en que pueden agruparse dichos atributos son básicamente cuatro:

1. Rasgos fisionómicos, particularidades anatómicas, expresiones, posturas y actitudes.

2. Todos los posibles componentes y características del atavio, incluyendo el tocado y el arreglo del cabello.

3. Los objetos y figuras de todo género que acompañan a la figura principal.

4. Los colores que se adjudican a la figura o a cualquiera de sus otros elementos o atributos.

Pues bien, si analizamos conforme a estos principios las estampas del Ripa que tanto repugnaban a Gravelot y Cochin, observaremos que en

26 Cf. la introducción de Giuseppe Plessi al Dizionario de Cecchini citado en la nota $3, \mathrm{p}, \mathrm{xv}$. 
lo fundamental se trata de una figura no humana, como la serpiente enroscada (con busto de mujex) que simboliza la Eternidad, o bien de figuras compuestas de elementos heteróclitos que imposibilitan su credibilidad anatómica. Así sucede, por ejemplo, con la Concordia invencible, representada en una figura con tres caras, seis brazos y seis piernas; el Fraude, que ostenta dos rostros, patas de águila y cola de sierpe; la Gula, con cuello de grulla y vientre deforme; el Engaño, hombre cuyas piernas terminan en colas de serpiente, etcétera.

Como puede apreciarse, estos elementos afectan únicamente la primera de las cuatro categorías del esquema anterior.

Gravelot y Cochin evitaron, por lo general, duplicar elementos anatómicos y prescindir de todo aquello que restara verosimilitud natural al aspecto humano de una figura. No titubearon, empero, en conservar otros atributos irreales que pueden resultar menos chocantes (por más habituales y aceptados en el arte occidental), como alas o llamas que irradian de la cabeza.

Se da también el caso de que, a pesar de sus críticas a la monstruosidad, los autores se dejaron llevar por el peso de la convención, mostrándose incapaces de imaginar una nueva figura adecuada: así sucede precisamente con una de las imágenes que le censuraban a Ripa, la del Fraude o Engaño, representada en forma de "mujer de rostro agradable, pero con piernas que terminan en colas de serpientes"; ${ }^{27}$ sin embargo, han prescindido de los dos rostros y las patas de águila de la estampa de Ripa. Además, merced a la posición asignada a la figura, recostada en el suelo, logxaron disminuir el impacto bizarro.

Cuando se trata de un símbolo venerable como el de la serpiente de la Eternidad, ésta no afectó la forma de la figura en sí, pasando a convertirse en uno de los atributos acompañantes: la matrona que personifica el concepto sostiene en la diestra el símbolo en cuestión.

En lo que se refiere a la tercera categoría de atributos, procuraron ios autores no excederse en el número de objetos que porta la figura; cuando hay más de dos, tuvieron el cuidado de distribuirlos en torno o a los pies de la misma.

Hay que hacer notar qu Gravelot y Cochin no rechazaron los atributos más característicos de la iconología tradicional, y echaron mano de todo el repertorio del bestiario, la botánica y los objetos emblemáticos más convencionales. Sin embargo, cuando se trata de animales fantás-

27 Tromperie, en el artículo Sincérité del t. Iv, p. 91. 
ticos o cuando las bestias encarnan o expresan una característica difícilmente comprobable, los autores declaran sin ambajes su propio escepticismo. Al proponer, por ejemplo, el lagarto como emblema de la Afección advierten que lo han incluido "a causa de la afección, verdadera o falsa, que se atribuye a este animal hacia los hombres".

Se confirma así, una vez más, el impacto del pensamiento ilustrado, pues si bien Gravelot y Cochin aprovecharon la rica tradición emblemática precedente, la han sometido al imperio de lo probable, de lo verificable en el siglo de la observación racional y empírica, cuando la exploración científica iba destruyendo un caudal de mitos y leyendas.

Con ello, la iconología perdía en atractivo misterioso y fantástico lo que ganaba en cordura, sentido común, credibilidad (dentro del convencionalismo que entraña la personificación de lo abstracto).

No obstante, conviene recalcar que, con todo y las diferencias apuntadas y a pesar de la actitud crítica que los autores guardan hacia el trabajo de sus predecesores, es incontestable y abrumadora la deuda que tiene su obra con las imágenes codificadas por Ripa. Muchas de las personificaciones son idénticas en lo sustancial, como podrá comprobarlo quien se tome la molestia de compulsarlas una a una.

Más aún, algunos de los atributos que aparecen en la Iconologie par figures resultan incomprensibles si no se conoce el texto de Ripa. Tal cosa ocurre en el caso de la Castidad, donde aparecen una columna y algunas monedas desparramadas en el suelo no mencionadas en el texto. ${ }^{28}$

La relación de dependencia que éste guarda con la tradición instaurada por Ripa se pone también de manifiesto en los párrafos finales del "Discurso preliminar", donde los autores declaran cuál es el propósito que los ha animado: hacer la obra "necesaria a la educación de los jóvenes de uno y otro sexo (para lo cual) hemos procurado poner sin cesar la moral en acción, pintar las virtudes y los vicios bajo las formas que los caracterizan y con los colores propios, para hacer amar y practicar las unas y al mismo tiempo inculcar hacia los otros la aversión y el horror que inspiran" (esto último parece una justificación moral y expresiva de los resabios de monstruosidad).

28 Según Ripa, la columna significaría que la pureza de la dama no es fingida ni aparente sino durable y verdadera. "Las monedas que tiene al pie señalan que el huir de la avaricia es medio conveniente de conservar la castidad", Ripa, edición pađuana: 74. Debemos consignar aquí que hay a veces cierto descuido en la correlación entre texto e imagen en el libro de Gravelot y Cochin. En la estampa de la Emulación, por ejemplo, aparecen dos gallos a los que el texto no hace tampoco referencia alguna. 
Plantear la obra con el doble fin de servir de código a poetas y artistas y con un propósito didáctico-moral coincide totalmente con la idea que movió a Ripa a redactar su libro. Aun en esto, pues, es palmaria la dependencia entre ambos textos 29

Por lo que toca al aspecto estilístico y formal de las imágenes, cabe señalar algunas características.

La primera de ellas es el uso constante de composiciones múltiples,

29 Conviene recordar un paralelismo análogo a la ambigua actitud de Gravelot y Cochin: el simultáneo rechazo y apego a la tradición de Ripa demostrados por el célebre historiador y esteta Johann Joachim Winckelmann. Ya en sus Ideas sobre la imitación de las obras griegas en la pintura y en la escultura (1755), Winckelmann se mostraba partidario del uso de alegorías para "dar a entender las ideas generales". Pero, decia, "el artista encuéntrase aquí como en un yermo... (y) desearía tener reunida una sabia provisión de estudios, de la qual pudiese extraer las imágenes sensibles, significativas y concretas de las cosas que no lo son. Una obra cabal de esta especie no existe todavía: los ensayos realizados hasta ahora no son muchos ni alcanzan elevadas miras". Y precisa después: " $\mathrm{El}$ artista ha de menester una obra que contenga las figuras e imágenes simbólicas de toda la mitología, las imaginadas asimismo por los mejores poetas antiguos y modernos; que contenga también entre sus páginas las creaciones de la filosofía esotérica de muchos pueblos y las representaciones que se hallan en los monumentos pétreos de la antigüedad, en las monedas, medallas y utensilios diversos; es decir, el artista necesita todos aquellos materiales de los que han surgido poéticamente las ideas universales... . El buen gusto de nuestra actual decoración orna. mental, que en los tiempos modernos se ha cortompido... podria ser depurado por medio de un fecundo y esmerado estudio de la alegoría, y de esta suerte la verdad y la razón podrían conservarse." (Cito por la traducción al castellano de Juan Ortega y Medina, en De la Belleza en el arte clásico. Selección de Estudios y Cartas, de J. J. Winckelmann, México, UNAM, Instituto de Investigaciones Estéticas, 1959, pp. 100-102).

Para suplir tal carencia, Winckelmann emprendió la preparación de una obra, que finalmente publicó en 1766 con el título de Ensayo de una alegoría especial para el arte (Versuch einer Allegorie besonders für die Kunst). El trabajo de Winckelmann comienza (como el de Gravelot y Cochin) con una serie de consideraciones acerca de los textos emblemáticos más comunes, como el de Valeriano y el de Ripa. Ninguno le satisface. Valeriano no ofrece, en su opinión, más que débiles conjeturas y discursos superfluos. Ripa demuestra una lamentable falta de conocimiento de los monumentos antiguos, y algunas de sus invenciones resuitan, afirma, francamente ridículas; la popularidad que, a pesar de todo, ha alcanzado la Iconología es claro indicio de la perversión del gusto moderno.

Winckelmann exige de la alegoria simplicidad, claridad y gracia. Con estas premisas en mente, se entrega pues a la formulación de un nuevo repertorio alegórico. Pero a fin de cuentas viene a caer en los errores que señalara en su critica, y termina por servirse de la erudición de los mitógrafos posclásicos tan despreciados por Addison y por Spence. Su repettorio alegórico, como el de Valeriano y el de Ripa, adolece también de "interpretaciones forzadas, de absurdos y de oscuridades", como ya sus propios contemporáneos se lo señalaron (Gordon, op. cit., 72).

Compárese, pues, este hecho con lo que acabamos de constatar para Gravelot y Cochin. 
reuniendo en una sola imagen personificaciones diversas. En principio, la idea es buena, pues el hecho de agrupar conceptos antitéticos introduce un elemento de conflicto, rico en posibilidades dramáticas.

Esto se combina con la importancia que los iconólogos en general, y Gravelot y Cochin en particular, concedían a la actitud corporal como elemento significativo para caradterizar las alegorías, lo cual puede hacer más expresivos los contrastes, como, por ejemplo, el que personifican las figuras de la Abstinencia y la Gula, la Alegria y el Tedio o la Celeridad y la Pereza.

Es frecuente encontrar expresiones fisionómicas vehementes y actitudes más dinámicas en la representación de pasiones y vicios, mientras que las personificaciones moralmente "positivas" suelen adoptar un continente más reservado y sereno; lo que recuerda el concepto tradicional de que la pasión es una alteración del ánimo (que se traduce en el gesto y en la fisonomía de quien la experimenta), y como tal, no era considerada ni ética ni estéticamente plausible. Pero esta diferencia de caracterización permite también que se establezcan, en principio, contrastes psicológicos interesantes.

En muchos casos los ilustradores han aprovechado bien las posibilidades de diferenciación y contraste que les ofrece el uso de distintas posiciones sobre el plano de profundidad (Concordia, Cionstancia) o en el sentido vertical (Benignidad, Felicidad), o bien la dirección contrastante en la pose de las figuras (Educación).

Sin embargo, no siempre está bien lograda la agrupación de los componentes. A veces, se desaprovechan las posibilidades dramáticas de la confrontación, obteniéndose débiles resultados (por ejemplo, en el emblema de la Castidad); o bien la solución resulta confusa (en la estampa de la Afabilidad y el Orgullo, la defectuosa separación entre ambas figuras, la poco feliz actitud que adoptan y la incierta posición de las plumas de pavorreal confunden al observador que, a primera vista, no logra dirimir lo que expresa cada figura; en la Humildad cuesta cierto trabajo distinguir a ésta de sus antagonistas). En ocasiones, las estampas pecan de recargamiento al contener un número excesivo de personificaciones o una mala distribución (por ejemplo, la estampa correspondiente a la Clemencia o la de la Afección). Y esto ocurre a pesar de que en diversas ocasiones los ilustradores se abstuvieron de representar la totalidad de las figuras descritas en el texto. Por lo general, el ilustrador no representó gráficamente aquellas nociones que suponen sólo variantes concep- 
tuales mínimas (por ejemplo, la Altivez en relación con el Orgullo, en la estampa correspondiente a la Afabilidad; o la Penuria con respecto a la Esterilidad en el artículo Fecundidad).

En otros casos, la ausencia de ciertas personificaciones es hasta cierto punto inexplicable, por las posibilidades expresivas que supuestamente contienen, como el Hambre, descrita y no representada en la estampa de la Fecundidad.

Sopesando las razones anteriores y, sobre todo, ante el ejemplo concreto de las imágenes, podemos concluir que en general las láminas más satisfactorias visualmente son las que contienen el menor número de figuras principales, una o dos cuando más.

Este hecho se relaciona, por otra parte, con el tamaño de las estampas. De inmedia to llama la atención la relativa pequeñez de la imagen. Recordemos la tendencia dieciochesca, en especial dentro del contexto rococó, hacia lo diminuto. Este fenómeno se aprecia sensiblemente en el formato de los libros que entonces se produjeron, lo que necesariamente repercute en la dimensión reducida de sus ilustraciones. Para confirmar la pequeñez de los libros, basta echar una ojeada a los retratos de damas que se complacen en leer sus minúsculos volúmenes (pensemos en las jóvenes lectoras pintadas por Fragonard, por ejemplo), y a los de caballeros, que gustaban portarlos en sus bolsillos o escarcelas. ${ }^{30}$

No es casual que los Goncourt y otros historiadores del arte dieciochesco hayan calificado a los ilustradores como vignettistes. Cochin el joven, en particular, se complacía en trabajar el grabado en petit.

Mas esta pequeñez no se limita únicamente al tamaño. Hay también una impresión de coquetería y delicadeza en las figuras, a pesar del atuendo de matronas que suelen portar o de su clásica semidesnudez, lo que les da un aspecto galante que hasta cierto punto no casa con la gravedad intemporal y el empaque solemne que naturalmente se espera de una imagen alegórica. No en balde, Gravelot y Cochin encontraron tan favorable eco entre sus contemporáneos, al mediar el siglo, satisfaciendo sus apetencias visuales. Véanse si no las láminas correspondientes a ciertos meses o estaciones del año (Mayo, Primavera, Otoño) las graciosas figuras de la Danza y de las Gracias, las del Aire y la Naturaleza y, muy apropiadamente, la del Placer, casi un cuadro de Boucher. Tal vez el efecto galante se deba, asimismo, a la plétora de putti, flores y frutos

30 Cf. Jean Adhémar: La grauure originale au XVIIIe siècle, Paris, Editions Aimery Somogy, 1963, p. 29. 
que rodean a las figuras, al aire de bienestar y despreocupación que afectan o a la gracia con que ondean al viento cabellos y paños.

Tenemos a veces la impresión, al hojear estas estampas, de estar contemplando un cuadro de costumbres más que una representación emblemática. Así ocurre con la del Estudio (que, entre paréntesis, me recuerda mucho la compasición y aun determinadas connotaciones de sentido del Napoleón en su gabinete, de Jacques-Louis David), con las de algunas ciencias y artes (Quimica, Grabado on talla dulce, Escultura) o bien con una estampa tan grata como la del temperamente Sanguineo.

Algunos textos subrayan a veces este efecto de cuadro costumbrista, como el que describe la Indiscreción (articulo Discreción) "bajo las formas de una joven inquieta, abriendo furtivamente una cartera llena de cartas y rompiendo el sello de una de ellas".

Esta dimensión costumbrista crea cierta atmósfera de trivialidad cotidiana que no deja de provocar tensiones con el grueso de las imágenes. En ocasiones sentimos inclusive que los autores se han excedido en la familiaridad un tanto vulgar de los emblemas, como la Antipatia (véase Deseo) representada por una joven que se espanta a la vista de unos sapos y ratones.

En esta tensión no resuelta entre lo intemporal y lo temporalmente circunscrito, entre lo antiguo y lo reciente, entre lo venerable e insólito y lo cotidiano e inmediato, la Iconologia de Gravelot y Cochin es obra de transición que parece anticipar algunos de los dilemas que habrian de enfrentar las artes del siglo xix.

Por otra parte, una de las características que los contemporáneos de Gravelot admiraban en su arte era su capacidad para sugerir en las viñetas el aspecto de una pintura, ${ }^{31}$ es decir, para dar la sugerencia de una concepción mayor en el reducido espacio del grabado en pequeño. Creo que es fácil percibir esto en la obra que comentamos, lo que constituye asimismo una diferencia notable respecto de la Iconologia de Ripa. En los grabados que ilustran las ediciones italianas del Ripa, a partir de 1603, las figuras aparecen aisladas, con una mínima indicación del terreno que pisan; pero nada más, ni un accesorio superfluo, nada que sugiera un entorno que localice la abstracción en un espacio y un tiempo definidos. Pensándolo bien, este estilo desnudo, despojado, es el más

31 Edmond y Jules de Goncourt: L'art du XVIIIe siècle et autres textes sur l'art, Paris, Hermann (Miroirs de l'art), 1967. pp. 137-138. 
propio para representar abstracciones mentales, que se supone funcionan a manera de lenguaje universal, de ninguna manera particularizado.

El cuidado que ponen Gravelot y Cochin en ubicar muchas de sus figuras en un ámbito diferenciado es, pues, otro motivo más de contradicción latente con el lenguaje emblemático. $\mathrm{Y}$, de nuevo, lo que ganan así las imágenes en variedad y atractivo galante es a expensas de grandeza misteriosa y sugestiva.

\section{IV}

Me he extendido en el comentario de la obra francesa porque la edición mexicana no es sino una labor reproductiva que no modifica el original salvo en puntos relativamente secundarios. Mas esto no quiere decir que carezca de interés puntualizar estos aspectos; habremos de referimos, además, a las personas a quienes so debe la publicación.

He logrado averiguar muy poco acerca del traductor, prologuista y anotador del texto, el licenciado Luis $G_{n}$ Pastor. Su nombre no aparece incluido en ninguno de los diccionarios biográficos que se han publicado en el pasado siglo ni en éste, y sólo he podido recabar algunas noticias sueltas. La carátula de la Iconología nos informa que era catedrático de literatura en el colegio de San Juan de Letrán, poco antes de ser demolido (con lo que desapareció una institución educativa mexicana ciertamente venerable aunque ya decaída).

Con la restauración de la República, encontramos a Pastor dirigiendo "con mucho acierto" una academia especial de estudios preparatorios, según anuncia El Monitor Republicano del 7 de enero de 1869. ${ }^{32}$

Pastor fue también maestro de declamación. ${ }^{33}$ Practicó la poesía de circunstancias, como lo demuestra su participación en el entierro y la

32 Citado por Clementina Díaz y de Ovando en La Escuela Nacional Preparatoria. Los afanes y los dias, 1867-1910, México, UNAM, Instituto de Investigaciones Estéticas, 1972 , t. I, p. 33.

33 Enrique Olavamia y Ferrari consigna una funqión dramática desempeñada por alumnos de la clase de declamación de Pastor, celebrada en honor de Melesio Morales el 22 de mayo de 1869 y organizada por la Sociedad Filarmónica "en su salón de conciertos de la ex-Universidad" (Olavarría y Fenari, Reseña Histórica del teatro en México, 1538-1911. $3^{a}$ ed., ilustrada y puesta al día, de 1911 a 1961, México, Editorial Porrúa, 1961, t. Ir, p. 780)"

Agradezco al señor Jaime Cuadriello el haberme señalado las noticias sobre Pastor en el libro de Olavarría y Ferrari. 
función de homenaje en memoria del gran actor mexicano Antonio Castro, en el año de 1863. ${ }^{34}$ Colaboró Pastor en El Renacimiento' (1869), la importante revista dirigida por Ignacio M. Altamirano, en la que publicó dos poemas: "En la muerte de la niña Carmen Arellano" (típico ejemplo de "evasión estoico-cristiana") ${ }^{35}$ y "Fue mentira!" (sobre la traición de una seductora mentirosa sin la que el poeta, empero, confiesa no poder vivir).

No es, pues, la suya una poesía de altos vuelos. $Y$ aunque el licenciado Pastor parece haber gozado en vida de una cierta estima en los círculos educativos y artísticos, su nombre ha quedado casi enteramente olvidado. ${ }^{36}$

Su traducción de la Iconologia es esmerada. Mas indudablemente el aspecto más interesante de su colaboración en esta obra radica en las notas con que la enriqueció. Ya en el Prólogo (en el cual teoriza acerca de la múltiple utilidad de la alegoría y, por ende, de la iconología, sobre las líneas teóricas ya antes comentadas), el traductor advierte cuál será el objeto y el tenor de sus anotaciones: no sólo

explicar el origen y significación propia de las palabras con que se expresan los objetos representados en la alegoría, conocimiento que no está por demás a los artistas, sino... explicar otras maneras de representar alegóricamente los mismos objetos... Esto les servirá no sólo para que elijan Ia alegoría que más les convenga en algún caso, sino para formar otras nuevas con las ideas que éstas les sugieran.

34 Ibid., t.. I, p. 674 .

35 Huberto Batis: Indices de El Renacimiento, Semanario Literario Mexicano (1869), México, UNAM, Centro de Estudios Literarios, 1963, p. 91 Las colaboraciones de Pastor quedan contenidas en las pp. 508 y 511 del $t$ I de El Renacimiento, del que hay edición facsimilar (UNAM, 1979).

36 Consulté, infructuosamente, varios diccionarios biográficos. Dos diccionarios anteriores a la época en que parece haber destacado más el licenciado Pastor no dieron, obviamente, ningún resultado: el Diccionario Universal de Historia y de Geografia, 18535s., México, Tipografía de Rafael, Librería de Andrade, y el Manual de biografia mejicana o Galeria de hombres célebres de Méjico, Palrís, Librería de Rosa Bouret y Cía., 1857. Mas tampoco da ninguna noticia el Diccionario de Geografia, historia y biografia mexicanas, de Alberto Leduc y Luis Laxa y Pardo (para los artículos histó. ricos y biográficos) y Carlos Roumagnac (para los artículos geográficos), París, Librería de la viuda de G. Bouret, 1910. Ni tampoco, por supuesto, dice nada Eduardo L. Gallo (editor) en los tres volúmenes de Hombres ilustres mexicanos, México, Imprenta de I Cumplido, 1873-1875.

De los diccionatios del siglo xx consulté el Diccionario biográfico mexicano, de

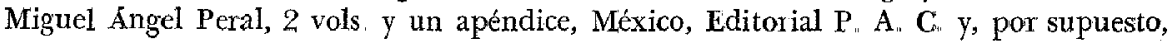
el Diccionario Porrúa No obtuve tampoco resultados. Las futuras búsquedas habrán de hacerse en hemeroteca: localizar, por ejemplo, alguna nota necrológica 
Esta observación me parece interesante, pues es claro que Pastorquiere promover el pensamiento emblemático, sustrayéndolo de la aplicación excesivamente rígida del código.

Las notas de Pastor exceden frecuentemente, y con mucho, la reducida dimensión de los textos originales, reintroduciendo aquel prurito de erudición que Gravelot y Cochin se habian esforzado en suprimir. Por lo general, comienzan con una serie de consideraciones etimológicas, un poco al estilo de las disquisiciones de los antiguos tratados mitográficos, con alguno de los cuales debe de haber estado familiarizado el comentarista, pues le gusta abundar en genealogías o en la simbología de ciertos objetos o atributos de deidades (por ejemplo, el caduceo de Mercurio o las plantas ligadas con los amores de Apolo).

Pero inmediatamente después de estos resabios humanísticos aparecen los afanes clasificatorios y las preocupaciones del cientificismo moderno. Pastor no desaprovecha ocasión para informar de las diversas ramas de un arte o una ciencia, o acerca de los conocimientos recientemente adquiridos en el campo de las ciencias naturales (por ejemplo, sus notas al aire y al fuego) o de la técnica (la agricultura). Arrikmete contra la falsa ciencia (la astrologia) y contra las ideas u opiniones que juzga erróneas (por ejemplo, los prejuicios sobre la importancia respectiva de las artes), muy en el papel de hombre ilustrado moderno. Traza esquemas del desarrollo histórico de alguna disciplina (la $B o-$ tánica, por ejemplo) o se extiende en la consideración de nuevas metodologías de conocimiento ( $v$. gr.: sus comentarios acerca del método experimental y el empirismo, en las notas a la Experiencia). Proporciona datos sobre las ideas o los instrumentos habituales en otras épocas (como cuando habla de la noción del arte entre los antiguos o de las distintas formas de arietes).

Pastor hace también inferencias de carácter sicológico o moral, como en sus comentarios sobre la Alegria o el Dolor. Gusta también de explayarse en las diferencias entre diversos sinónimos, y no vacila en hacer clasificaciones o jerarquizaciones de índole moral (como cuando distingue entre orgullo, soberbia, altivez, altanería, vanidad y presunción, o cuando traza la diferencia entre caridad y filantropía).

Pues Pastor insiste, en el prólogo y en las notas, que "el objeto de la presente obra no es de mera recreación y pasatiempo, sino procurar desenvolver el pensamiento moral y filosófico que se encierra en cada estampa, y dar a la vez una instrucción lo más extensamente posible... 
acerca de la significación de .. palabras y ... objetos" (nota a la Docilidad). Por eso se aventura también a emitir opiniones de cariz político (muy general, es cierto), por ejemplo con las notas correspondientes a los términos Docilidad y Economia.

A veces sentimos que afloran sus predilecciones personales como cuando, a fuer de maestro de declamación, estampa una larga nota al calce del artículo Elocuencia, a la que parangona con la poesía, ya que ambas nacen "de la misma fuente del corazón".

Finalmente, Pastor suele concluir sus notas informando al lector de otras posibilidades de representar los conceptos, aduciendo la autoridad de los antiguos iconólogos. En realidad, el comentarista sigue estrechamente las descripciones de Ripa, a quien por cierto intenta rehabilitar en el prólogo.

Pastor usó la edición de 1645 de la Iconologia, como se desprende de una observación que hace en la nota de América (donde afirma erróneamente que el "célebre iconologista... escribió por el año de 1645"), pero además por evidencias internas: un buen número de los emblemas a que se refiere Pastor no aparecen en la edición más reducida de Padua, 1611, pero sí en la veneciana de 1645 .

Con muy contadas excepciones, las sugerencias emblemáticas y aun parte de la erudición de Pastor dependen de esta edición del Ripa, como podrá comprobario quien coteje con dicho texto las notas de Pastor a los siguientes términos: América, Agricultura, Africa, Arquitectura, Aritmética, Asia, Caridad, Clemencia, Confianza, Clio, Discreción, Economia, Elocuencia, Emulación, Esperanza, Eternidad, Europa, Fortuna, Fuerza, Genio, Geografia, Las Gracias, Humanidad y Humildad.

En muy pocos casos dejan de coincidir las alegorías propuestas por Pastor con las de Ripa. Es posible que algunas de ellas sean invenciones propias del comentarista (como la del Arie militar moderno o la idea de flanquear la imagen de la Astronomia con las figuras de Ptolomeo y Copérnico, vicjísimo expediente, por cierto); otras podrían derivar de los capítulos sobre representaciones emblemáticas que trae $E l$ Museo Pictórico y Escala Óptica de Antonio Palomino (1715-1724) (como por ejemplo, Fe cristiana y Amor divino, aunque con variantes). Otras más, de tema relacionado con la mitología, como las figuras de las Musas y las de los Vientos (El Aire), tal vez provengan de alguna mitografía, o quizá más bien de algún diccionaxio de la fábula, como el de Pierre 
Chompré o el de F. Noël, que fueron tan populares en los siglos xvin y xix como los diccionarios iconológicos.

Por lo que toca a las estampas de la edición mexicana, poco hay que comentar realmente. El cambio más importante con respecto al original francés es que los grabados en talla dulce de éste han sido. transformados en litografías. El litógrafo mexicano sustituyó, además, el sencillo filete que enmarcaba las láminas francesas por una banda o faja decorada con una lacería simple de rombos y polígonos alargados en cuyo centro se ven óvalos ornados con rosetas oblongas. En el original la identificación de las imágenes figura en una sobria cartela rectangular, mientras que en la edición mexicana los títulos aparecen sin enmarca" miento alguno al calce de las estampas.

El taller litográfico encargado de la impresión fue el de Hipólito Salazar, "el patriarca de la litografía en México", ${ }^{37}$ que parece haberse especializado en trabajos reproductivos de obras europeas. De la litografía de Salazar salieron la edición mexicana de Pablo y Virginia (1843) de Bernardin de Saint-Pierre, publicada por José Mariano Fernández de Lara en base a la edición europea de Curmer, 1838; la V'ida de Jesucristo, sacada de la Historia Universal de Bossuet y publicada por Vicente García Torres, también en 1843. En 1860 Salazar litografió Los ciento uno Roberto Macario, sobre las planchas de Daumier y con textos de Maurice Alhoy y Louis Huart, y en 1865-1866 las láminas de la Iconología.

Salazar realizó un trabajo fidelísimo, con las diferencias, claro está, que son de esperar entre el grabado en metal y la piedra litográfica y que atañen sobre todo a las texturas, mas también a cierta calidad de la línea.

En cuanto al número y ordenamiento de las láminas de la edición mexicana, hay alguna divergencia del original. Más significativo que la permuta en el orden de algunas estampas me parece la supresión de otras. He advertido antes que el tomo publicado reproduce los dos primeros volúmenes de los cuatro que comprende la edición original. Pues bien, de estos dos volúmenes franceses no se estamparon en México los títulos siguientes: Automne, Chymie, Colérique, Courage, Danse, Doctrine, Eau, Fidelité, Finesse, Flatterie, Flegmatique, Le bon et le mauvais Fénie, Gravure en taille douce, Histoire e Hymen.

37 Manuel Toussaint: La litografia en México en el siglo XIX. México, Estudios Neolitho (Ediciones facsimilares de la Biblioteca Nacional de México), 1934, p. xxi. 


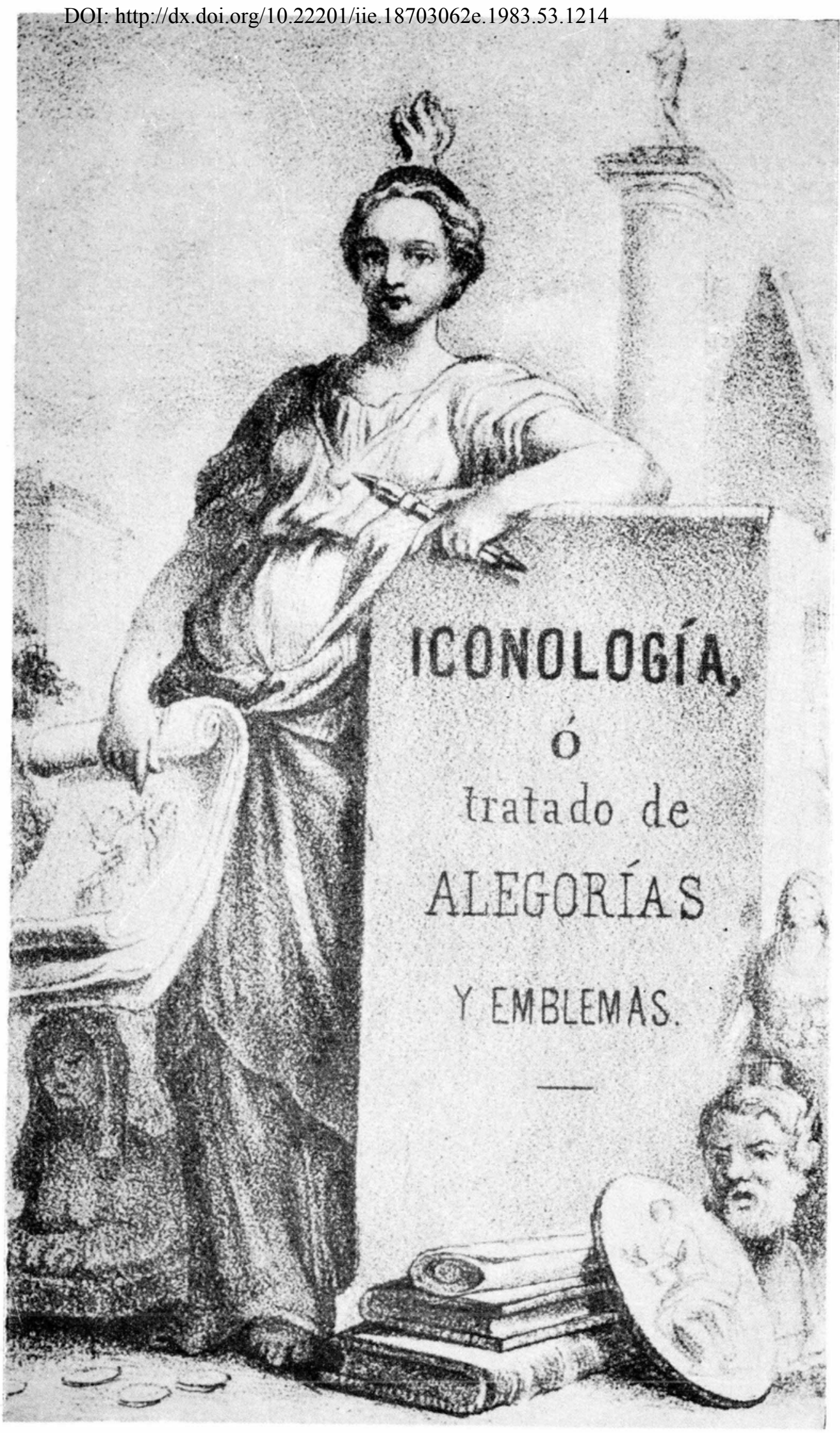


$\leftarrow$ Figura 1. El emblema de la ICONOLOGfA, o “ciencia de las imágenes", encabeza la serie de alegorias descritas por Gravelot y Cochin: en derredor de la figura que la significa, y en cuya cabeza brilla "la llama del genio", se ven monumentos antiguos, "las autoridades en que pretende apoyarse y que sirven de base a esta ciencia".

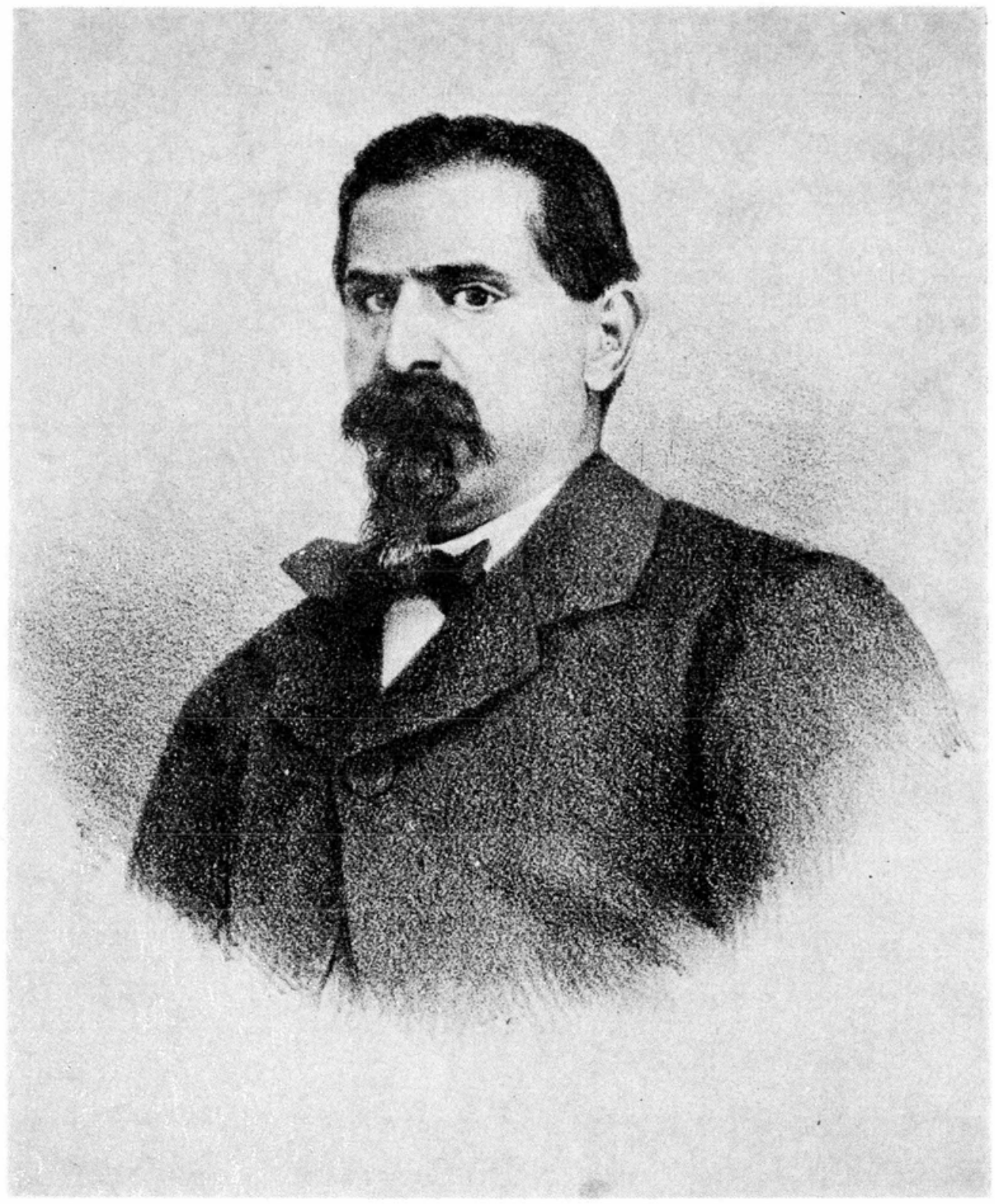

Figura 2. Retrato del traductor mexicano de la ICONOLOGiA. Esta lámina aparece frente al Prólogo escrito por él. 


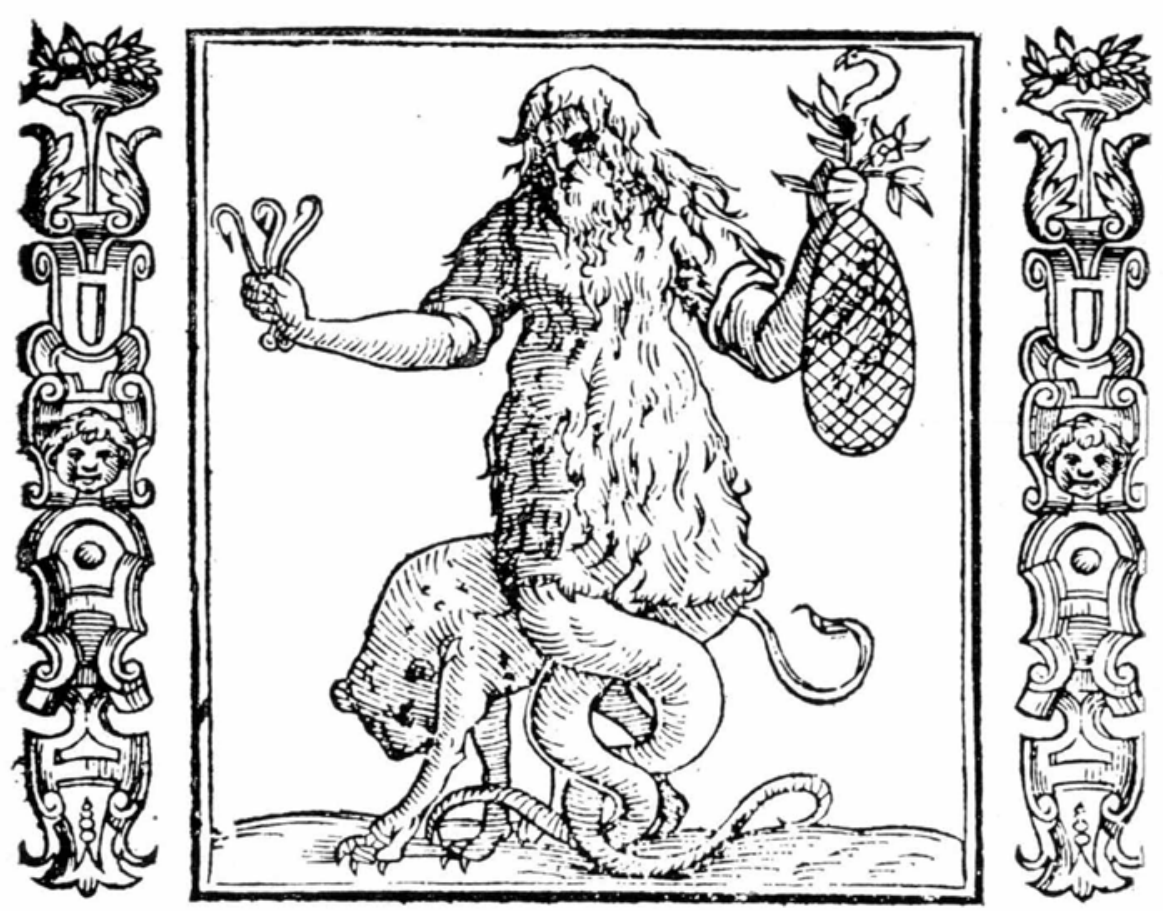

Figura 3. El ENGA T̃O, según Ripa: un ejemplo de las figuras monstruosas censuradas por los autores de la Iconología.
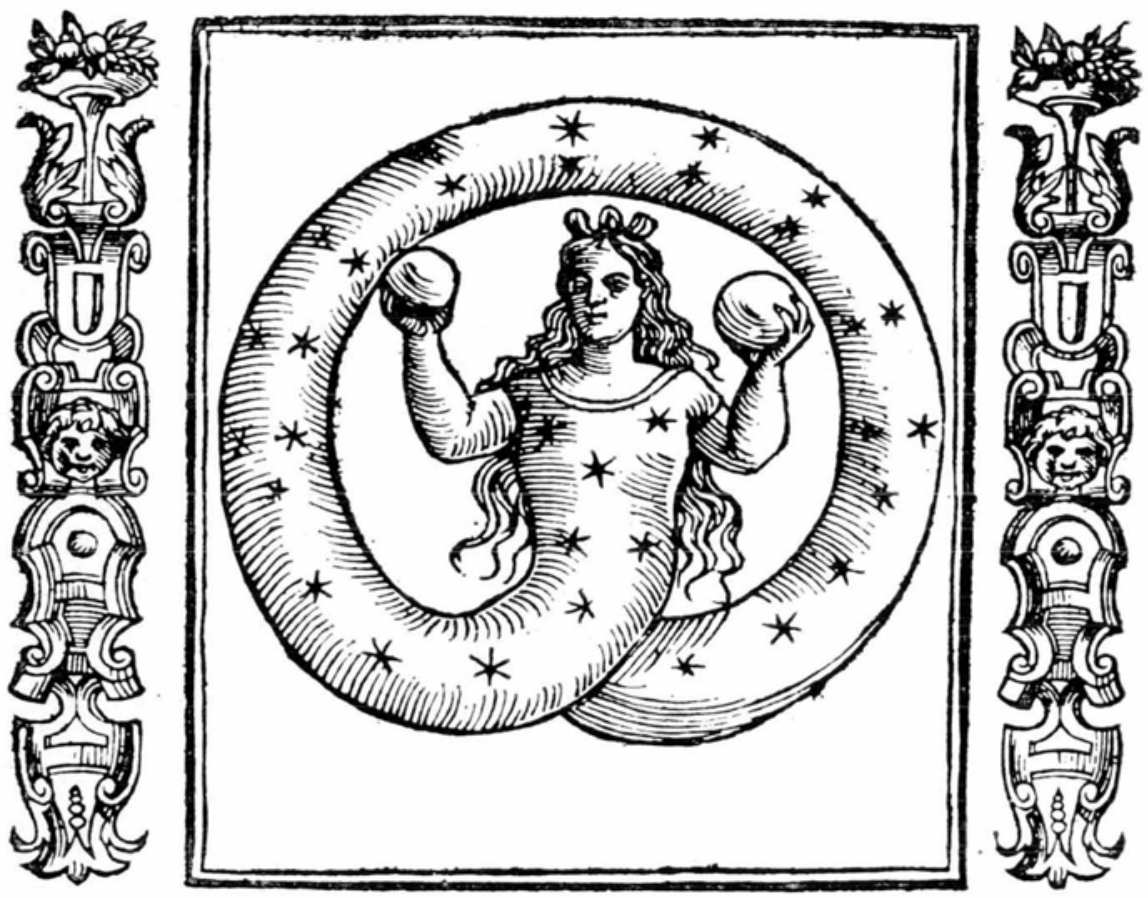

Figura 4. La ETERNIDAD, según Ripa. 


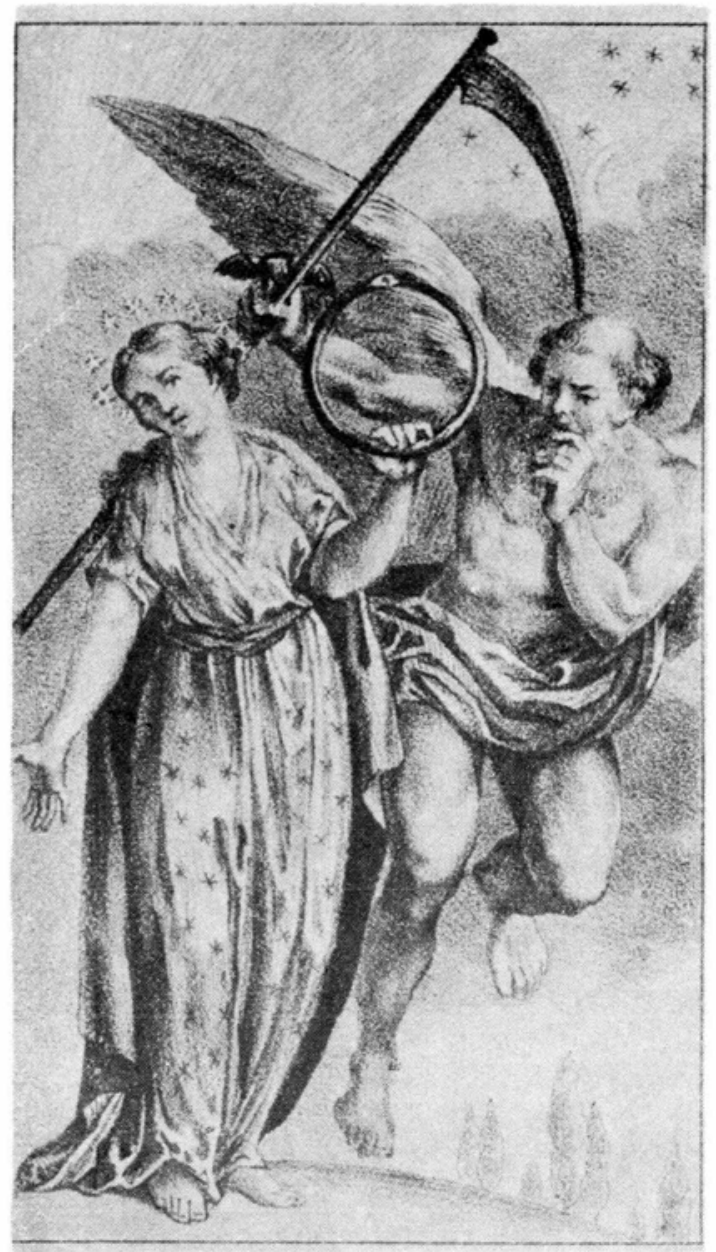

Figura 5. La ETERNIDAD, según Gravelot y Cochin: con un vestido salpicado de estrellas (que los antiguos creían eternas), lleva en la diestra el venerable círculo de la serpiente mordiéndose la cola; detrás de ella vuela el Tiempo, con reloj de arena y guadaña
Figuras 6 y 7 . La DANZA y el GRABADO, dos bellas composiciones de Gravelot y Cochin que inexplicablemente no figuran en la traducción mexicana.

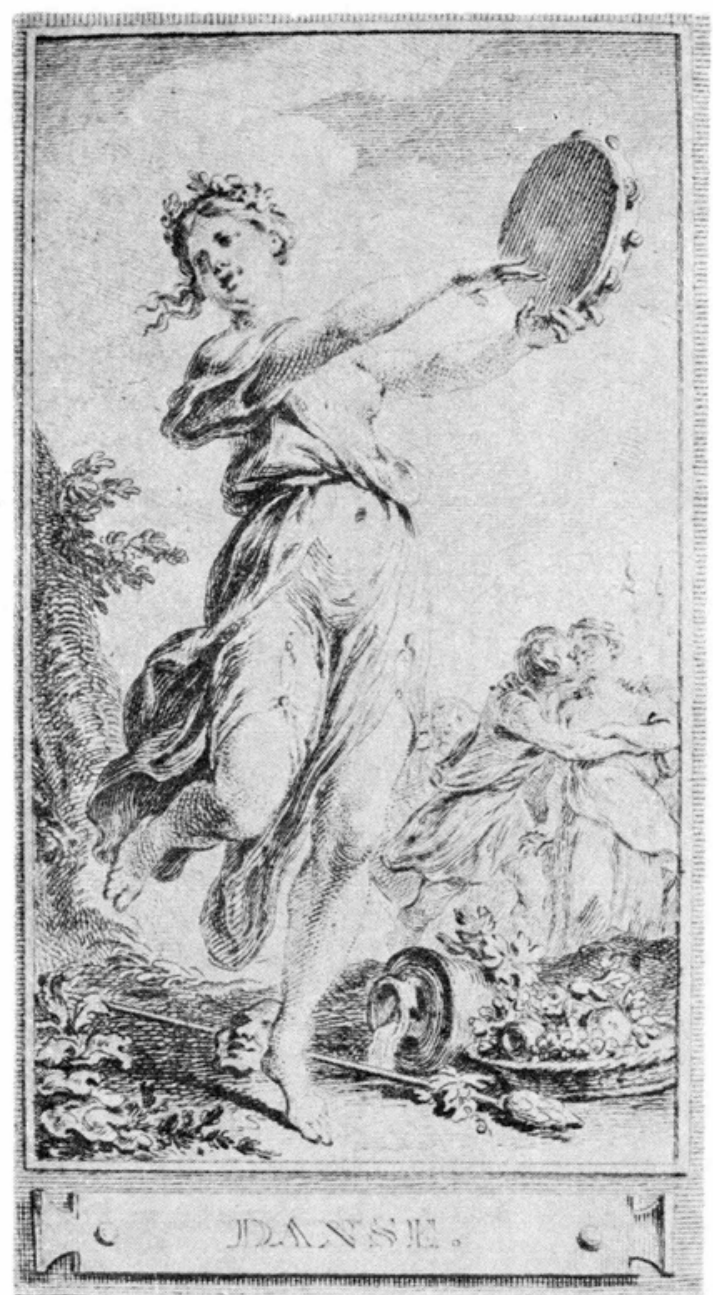


DOI: http://dx.doi.org/10.22201/iie.18703062e.1983.53.1214

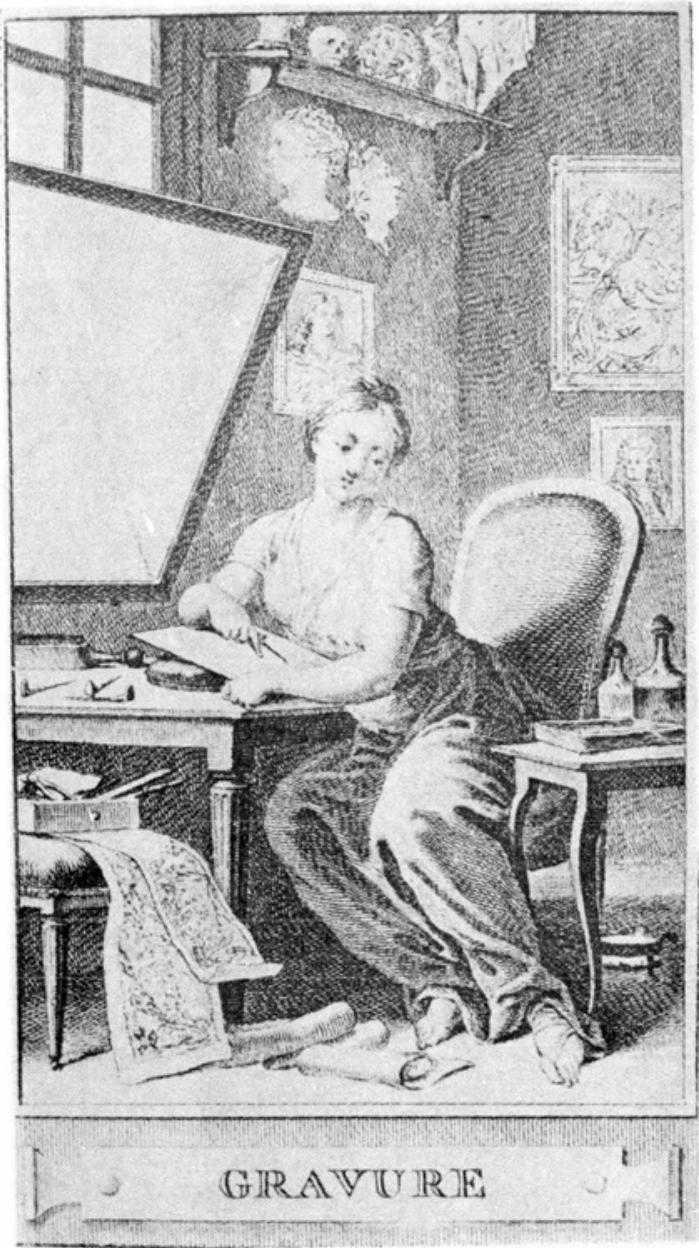

Figura 7 .

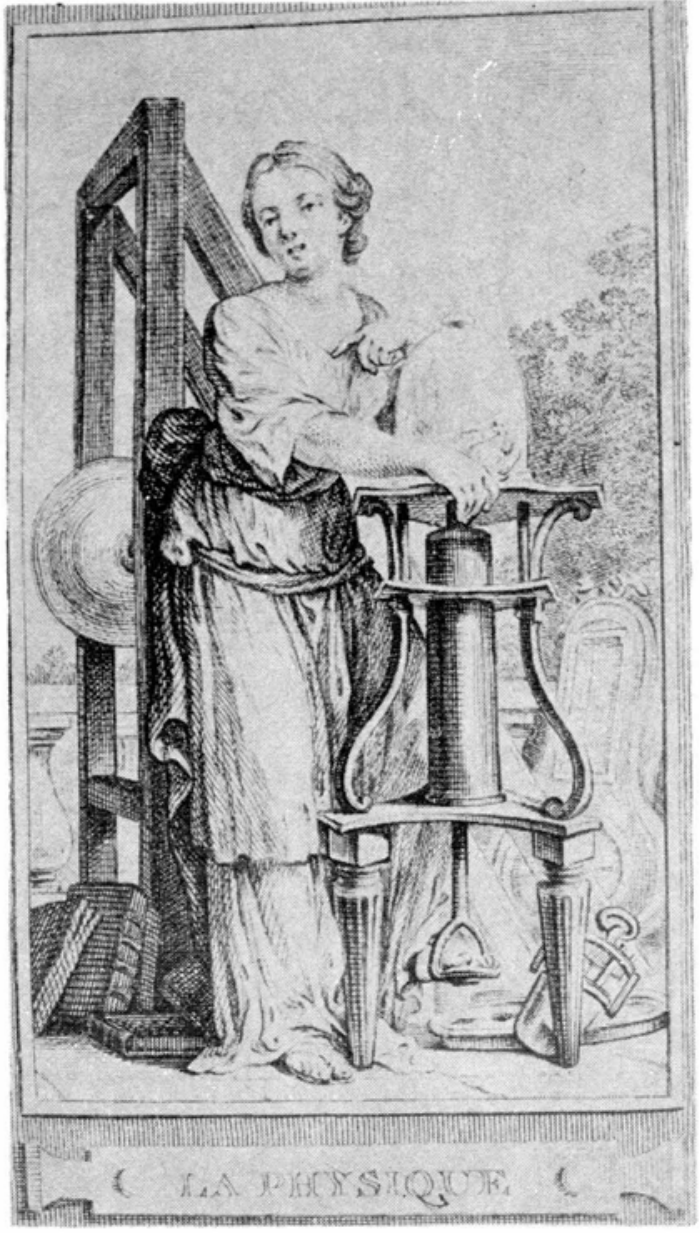

Figura 8. La FíSICA, rodeada de aparatos científicos: claro ejemplo de las nuevas tareas exigidas a la emblemática por los intereses propios del Siglo de las Luces. 
DOI: http://dx.doi.org/10.22201/iie.18703062e.1983.53.1214

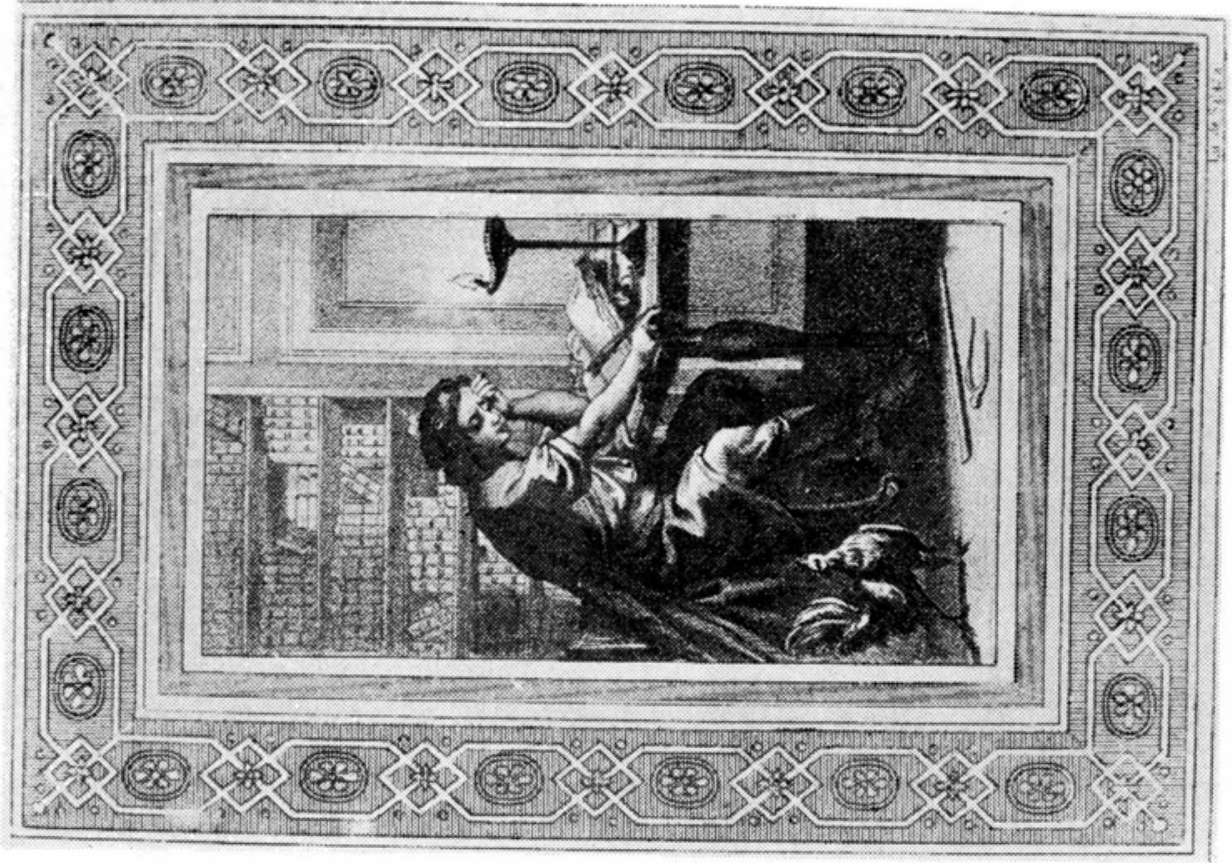

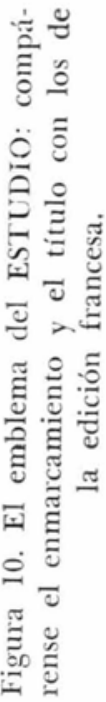

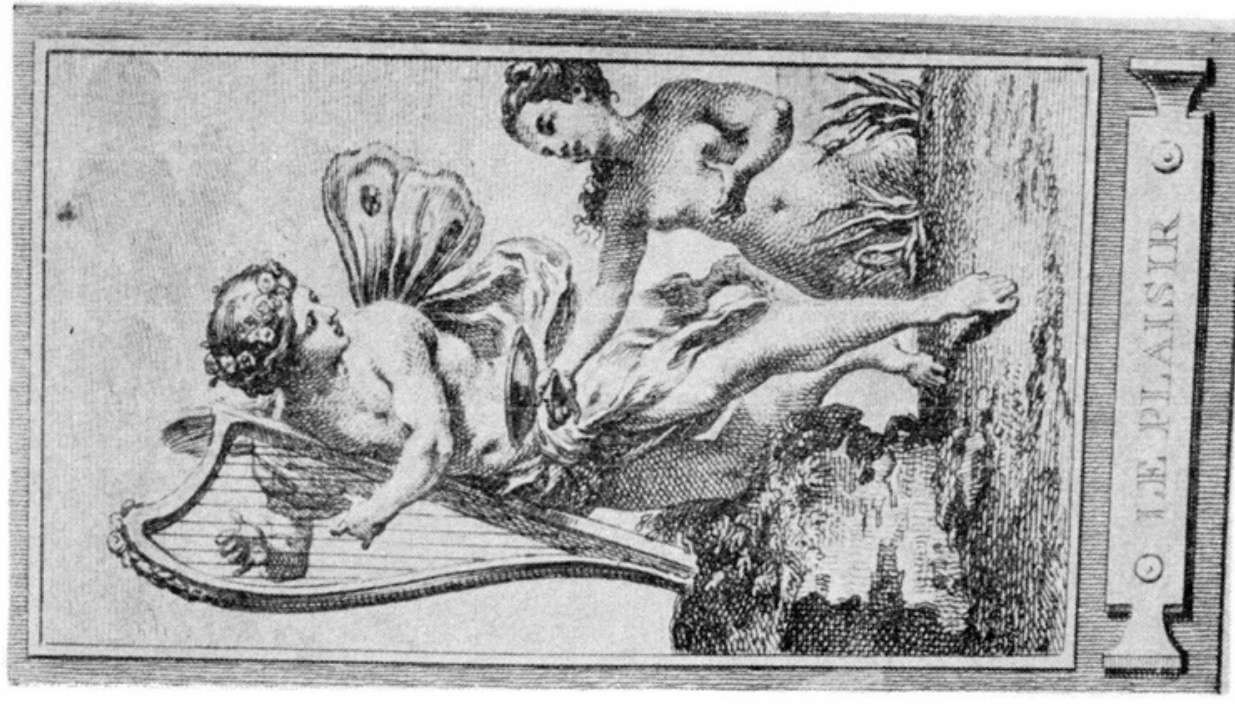

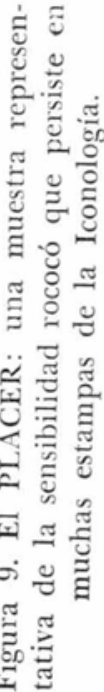


Figura 11. La EDUCACIÓN "en una mano tiene la vara del castigo y con la otra sostiene un árbol tierno contenido por unos apoyos para hacerlo enderezar"; al fondo, la Ignorancia, con los ojos vendados y orejas de asno, avanza entre abrojos y espinas, rodeada de animales nocturnos.

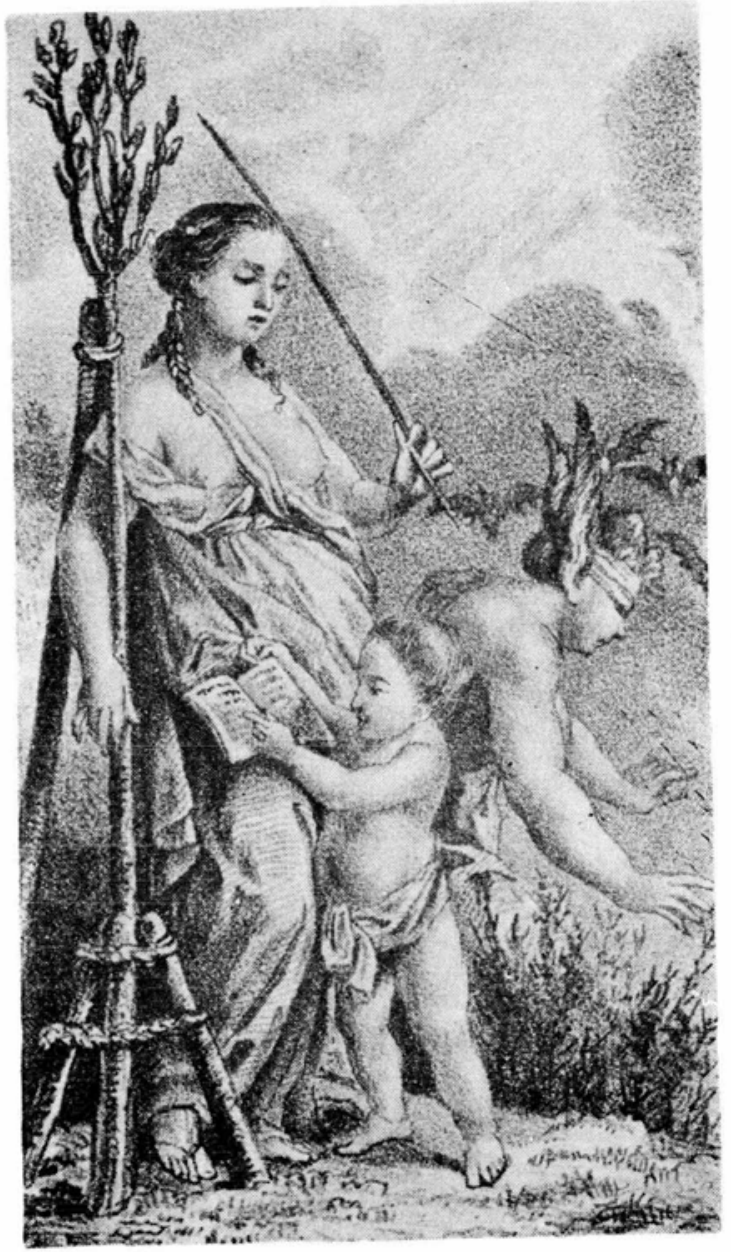

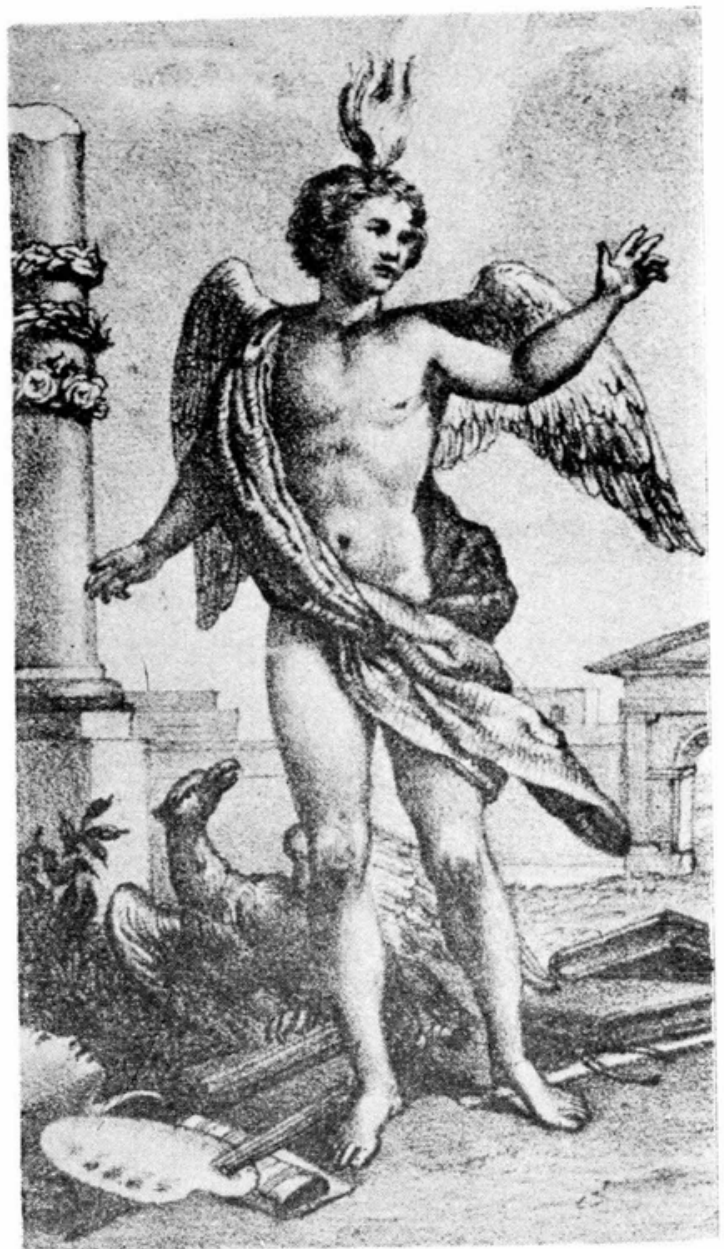

Figura 12. El GENIO, "don de la naturaleza" (idea significada por el rayo que cae sobre la figura) desarrollado por los conocimientos (véanse los atributos a sus pies), se eleva con audacia (águila) y logra brillar y obtener la gloria (flama sobre su cabeza; coronas ceñidas a la columna) . 


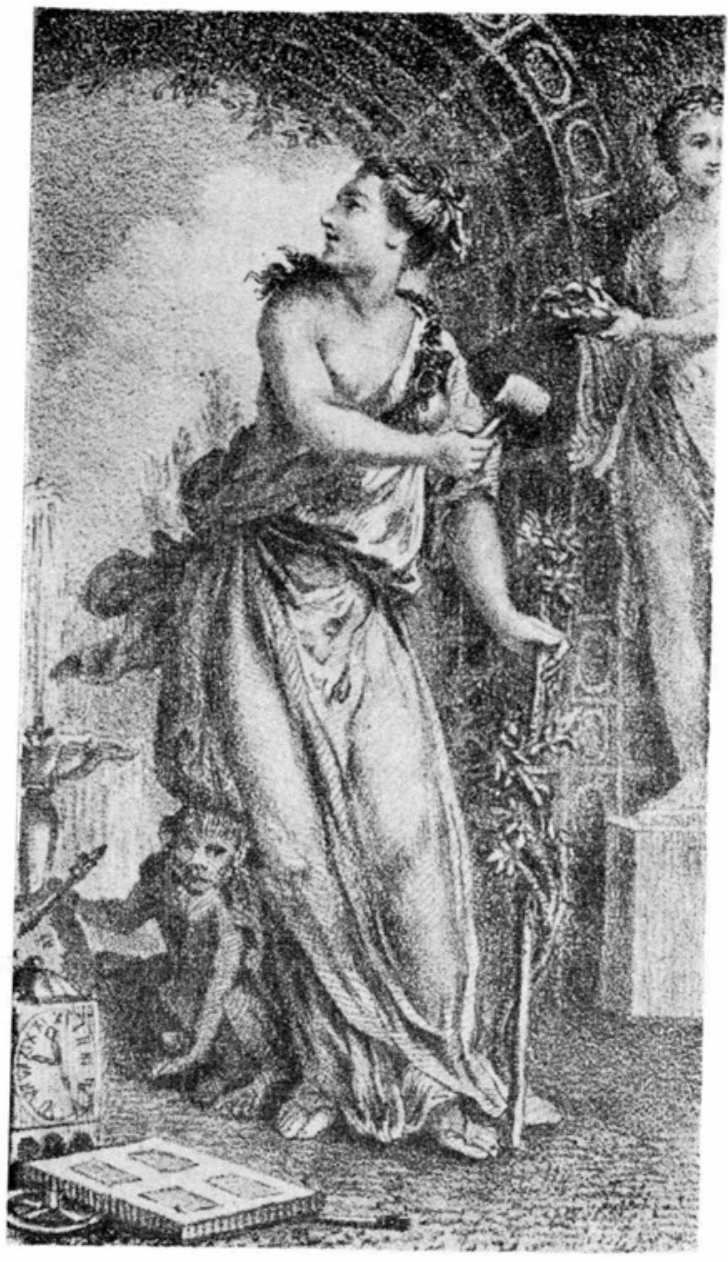

Figura 13. El emblema de las ARTES, o del Arte, "rival de la Naturaleza": una mujer "apoyada sobre un puntal, con cuyo auxilio una planta naciente llega a enderezarse y a crecer"; la acompañan un simio, "símbolo de la imita. ción", y Apolo que le ofrece una corona.
Figura 14. La ARQUITECTURA, con plomada, compás, planos y a sus pies, por supuesto, el Tratado de Vitruvio.

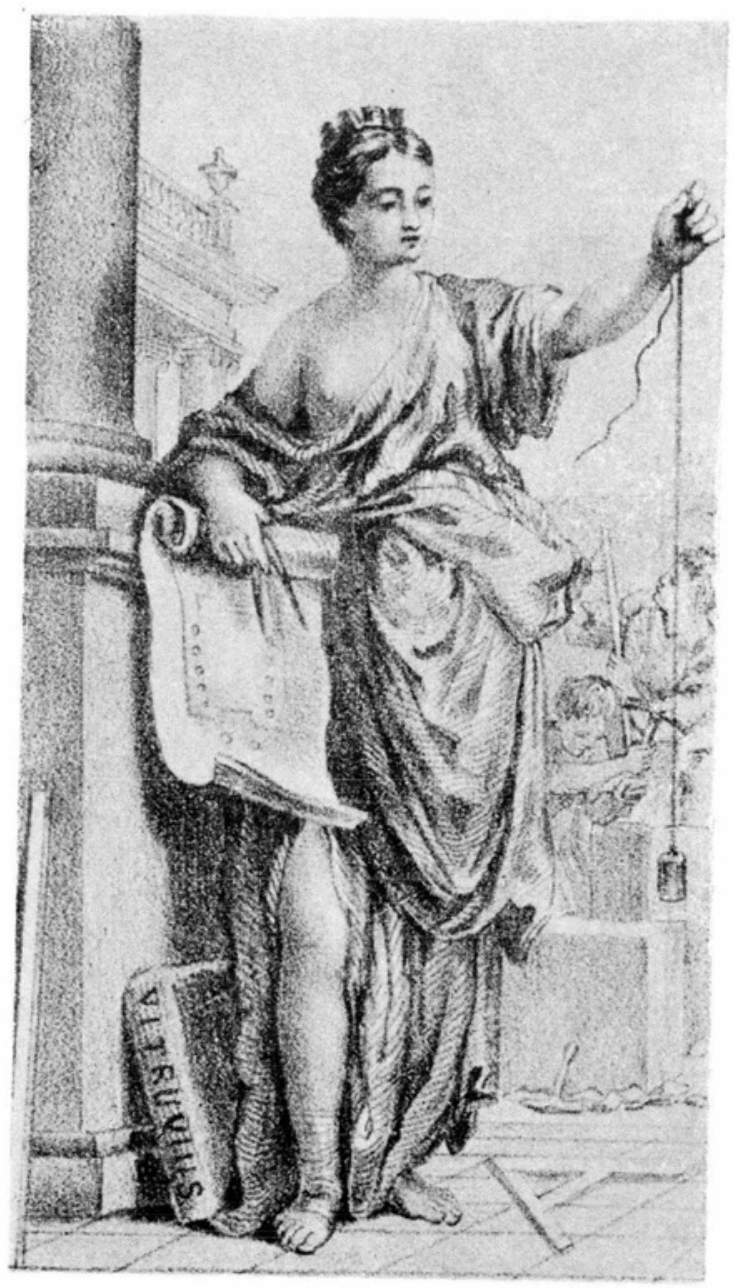


DOI: http://dx.doi.org/10.22201/iie.18703062e.1983.53.1214

Figura 15. EUTERPE, musa que preside la música y a quien se atribuía la invención de la flauta, símbolo del "arte de agradar".
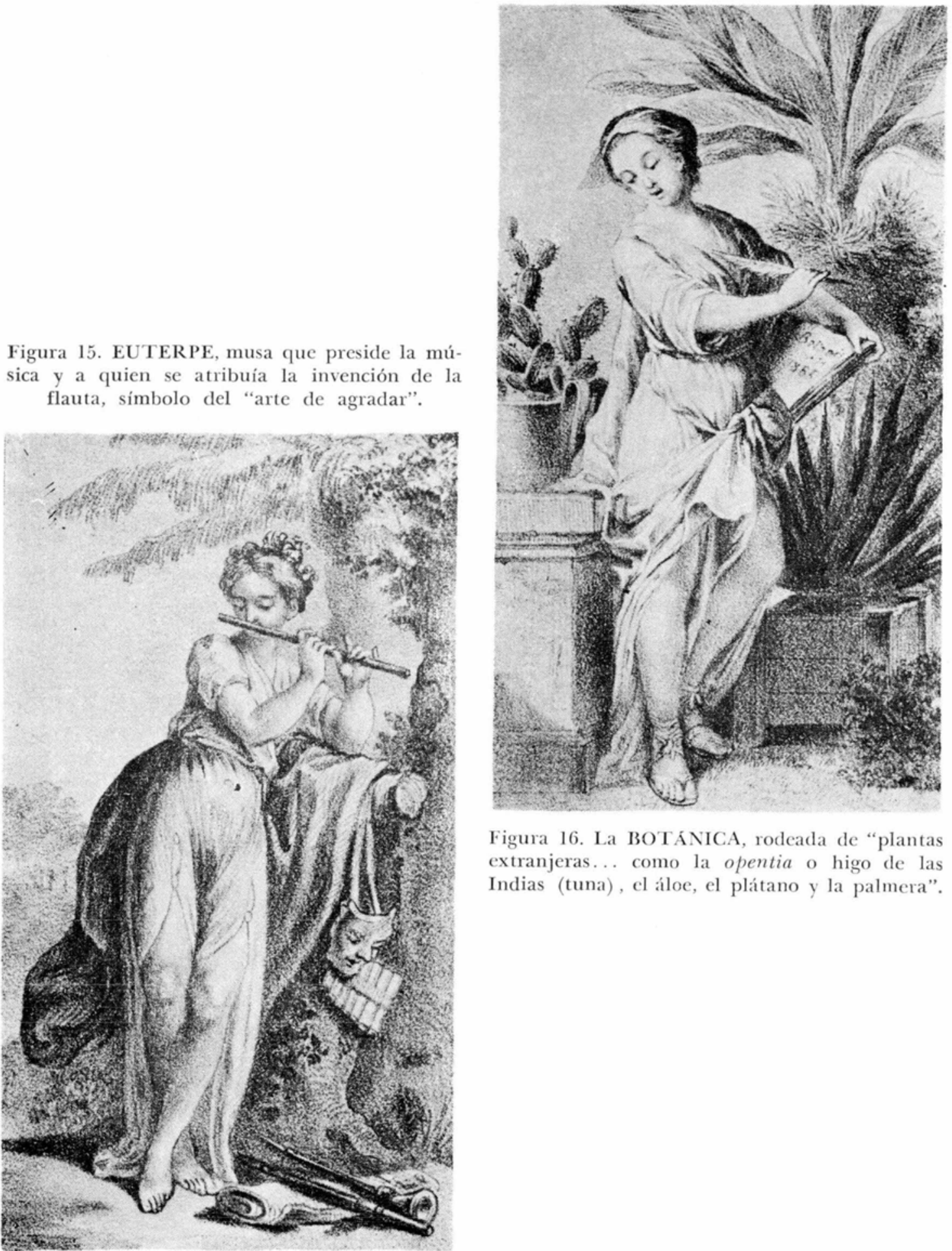

Figura 16. La BOTÁNICA, rodeada de "plantas extranjeras... como la opentia o higo de las Indias (tuna), el áloe, el plátano y la palmera". 


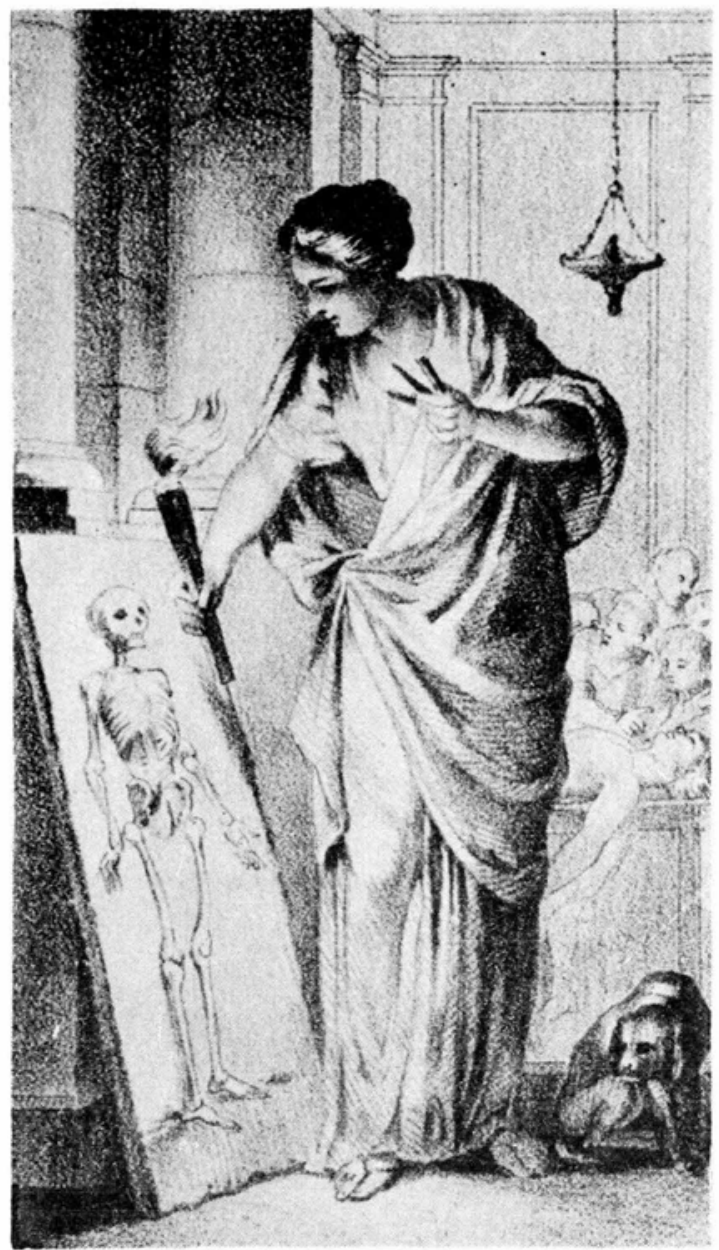

Figura 17. La CIRUGIA, representada en su doble aspecto: teórico ("la llama de la observación" que le da el conocimiento del cuerpo humano) y práctico (la lanceta). Un perro que se lame una herida simboliza "la dulzura y suavidad con que debe ejercerse este arte". Al fondo, "una Escuela de Anatomía".
Figura 18. La GEOGRAFiA, compás en mano, mide los grados sobre un globo celeste y señala con la izquierda una esfera armilar. Mapas y libros completan el emblema.

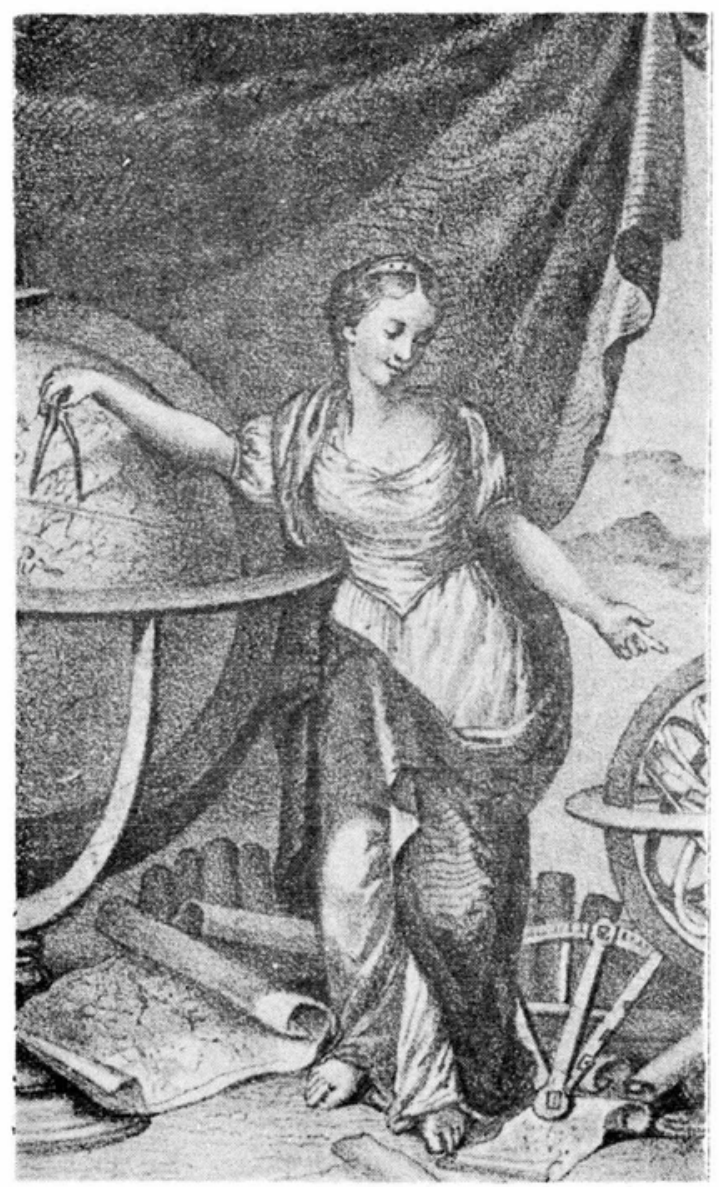




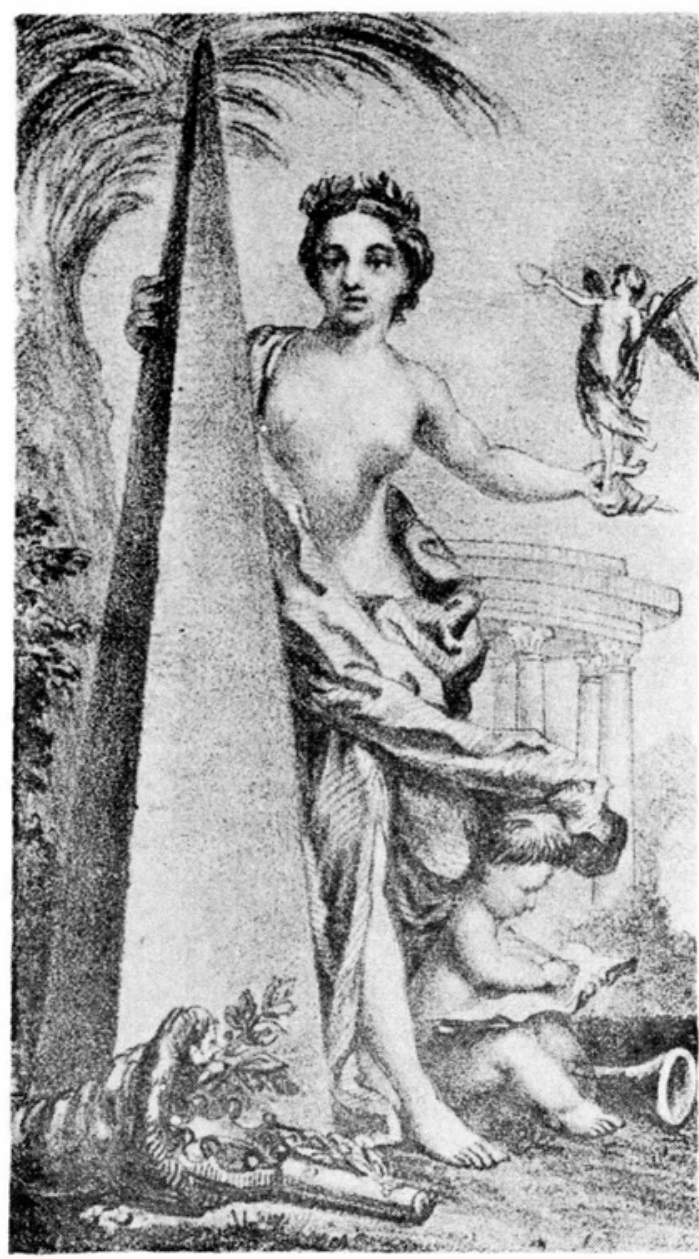

Figura 19. La GLORIA tiene en una mano la Victoria, atributo de los conquistadores, y abraza con la otra una pirámide que representa a "los monumentos erigidos por el amor de los pueblos a la memoria de los buenos reyes"; a sus pies escribe el Genio de la Historia.
Figura 20. Los tradicionales atributos emblemáticos de la AMÉRICA: el atuendo de plumas, el arco y las flechas, el caimán y la cabeza cercenada (que expresa "la inhumanidad de los habitantes de esta parte del mundo"), más la pipa de la paz.

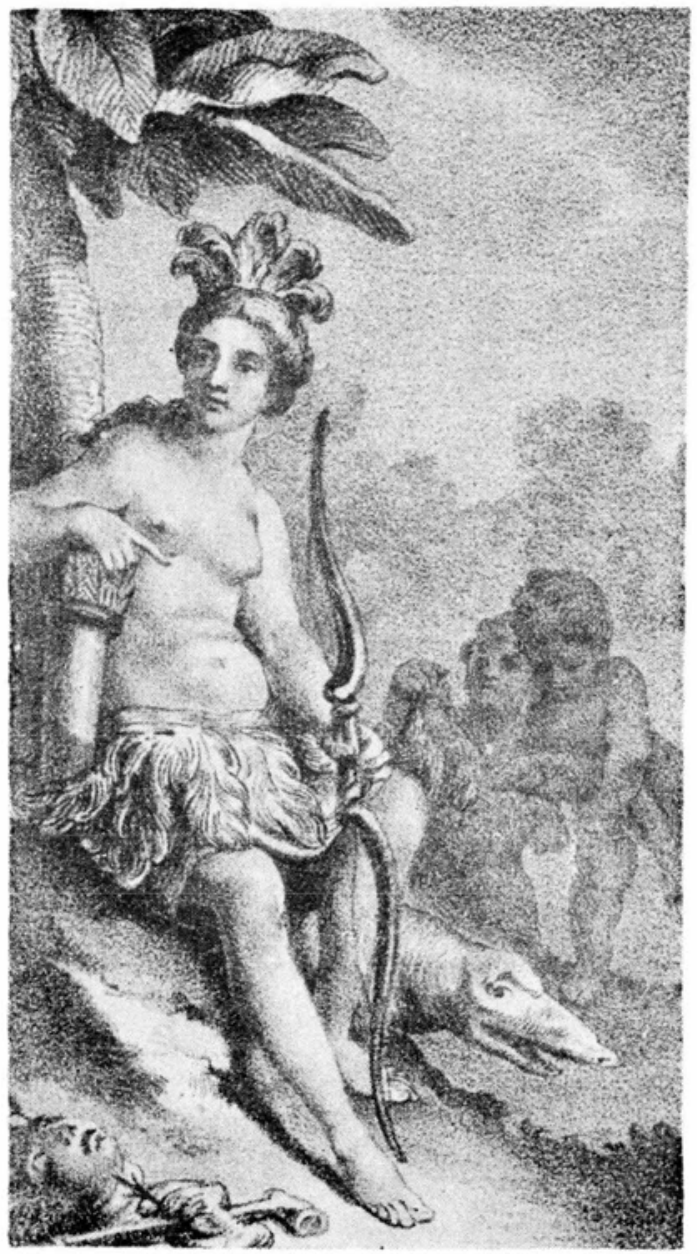


DOI: http://dx.doi.org/10.22201/iie.18703062e.1983.53.1214

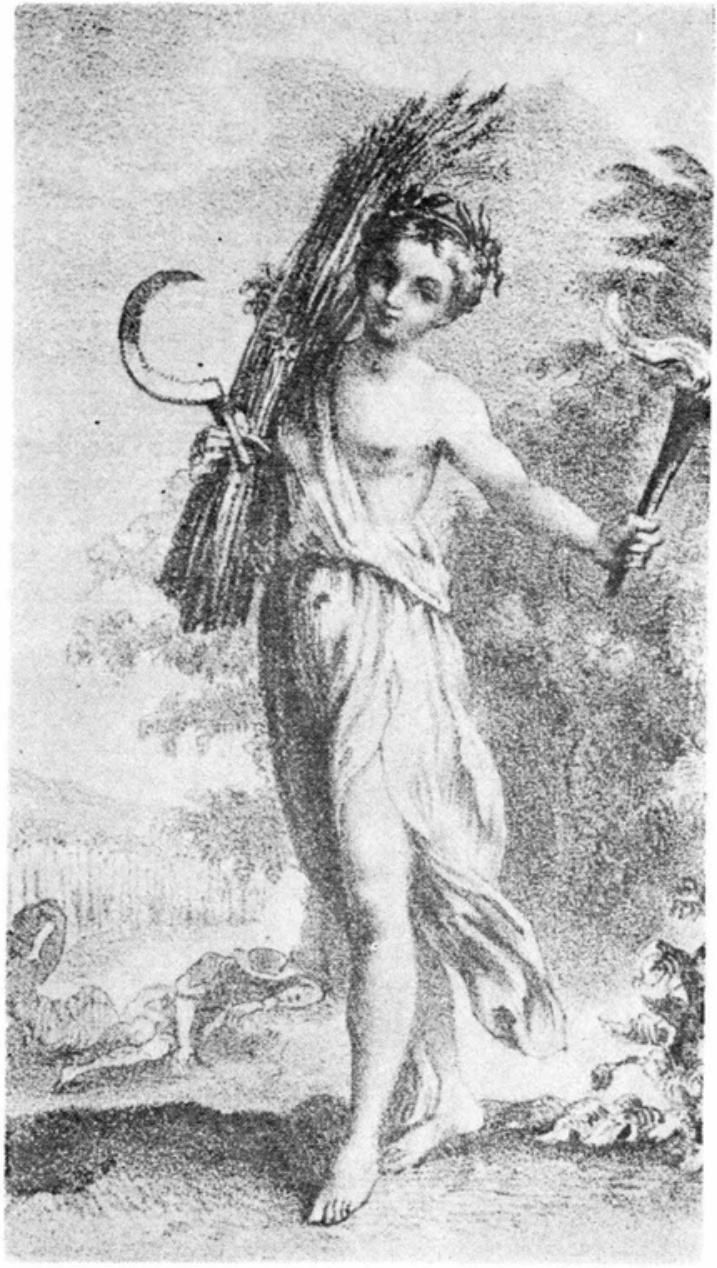

Figura 21. La alegoría del ESTIO, coronada de espigas, con la hoz y un manojo de trigo, "el más precioso de sus dones".
Figura 22. El FUEGO, uno de los cuatro elementos, bajo la figura de una sacerdotisa de Venus, acompañada de la salamandra y el ave fénix.

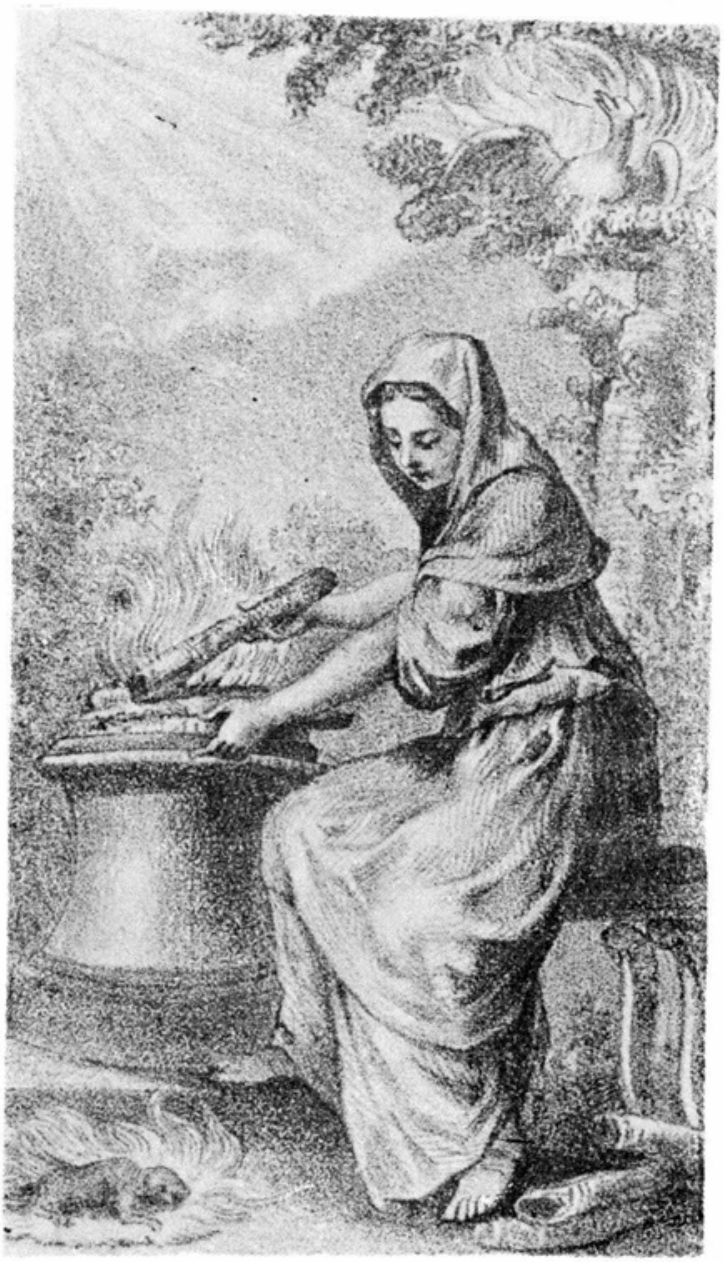




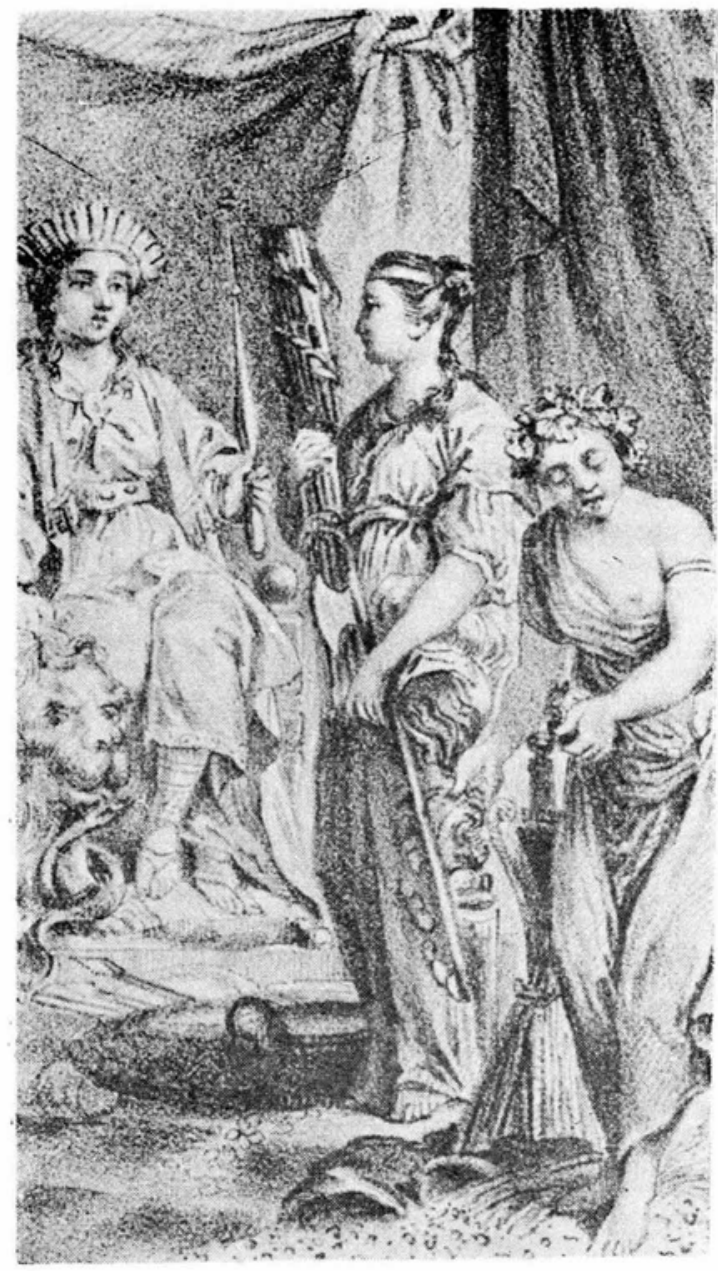

Figura 23. Los GOBIERNOS, representados en tres de sus formas posibles: la Monarquía, entronizada y apaoyada en un león; la Aristocracia, al centro, con un haz de varas y un hacha; y. la Democracia, con "un timón sostenido por multitud de varillas".
Figura 24. EI DOLOR simbolizado en un viejo abatido y enlutado, junto a una tumba coronada por una urna funeraria, que "anuncia el término fatal a que nos conduce el dolor".

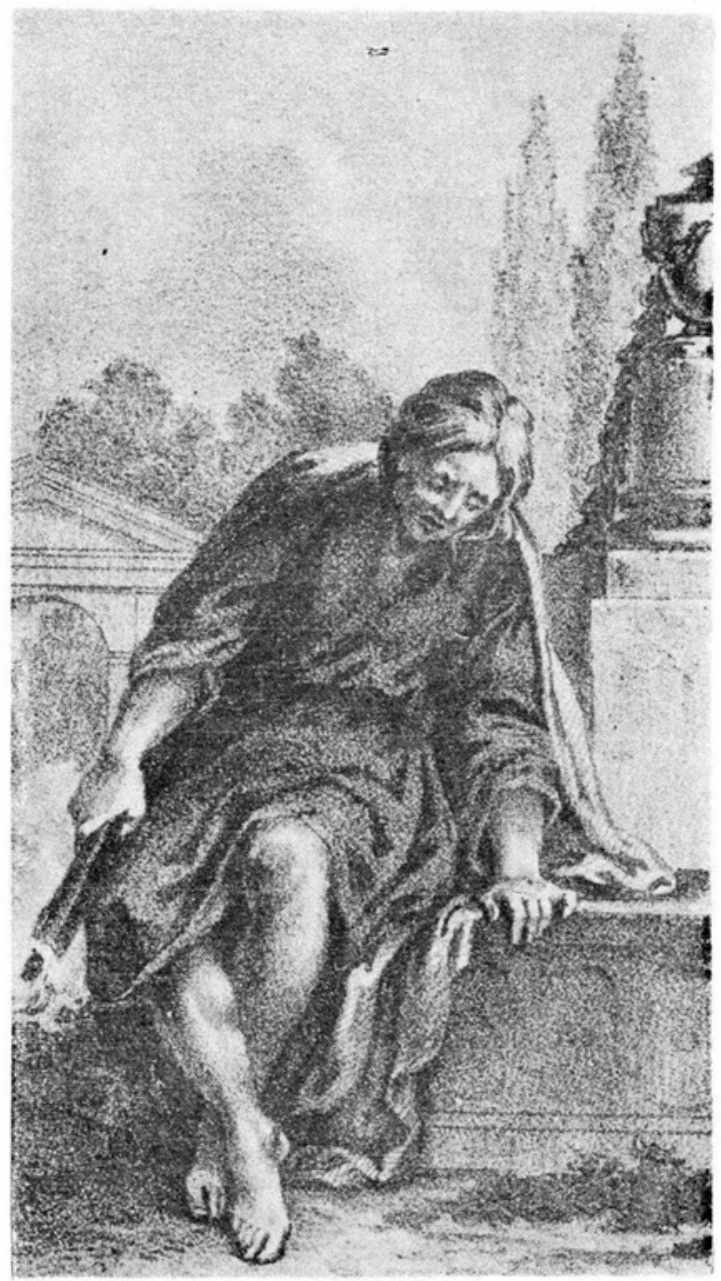




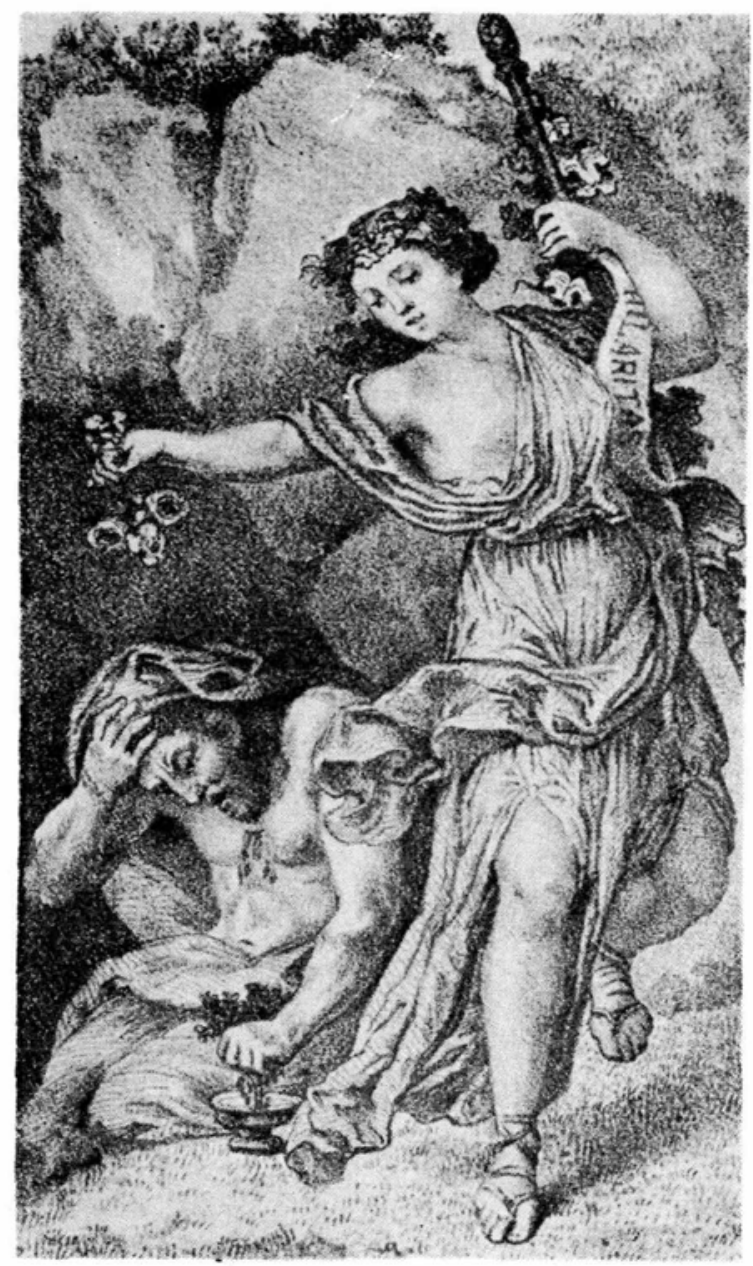

Figura 25. La juvenil y vivaz ALEGRí contrasta con el Tedio, herido en el corazón y exprimiendo en un cáliz el jugo del ajenjo.
Figura 26. La CELERIDAD, flanqueada por atributos apropiados (el gavilán, el rayo), vuela encima de una figura que simboliza tanto la Lentitud (la tortuga) como la Pereza (el perezoso).

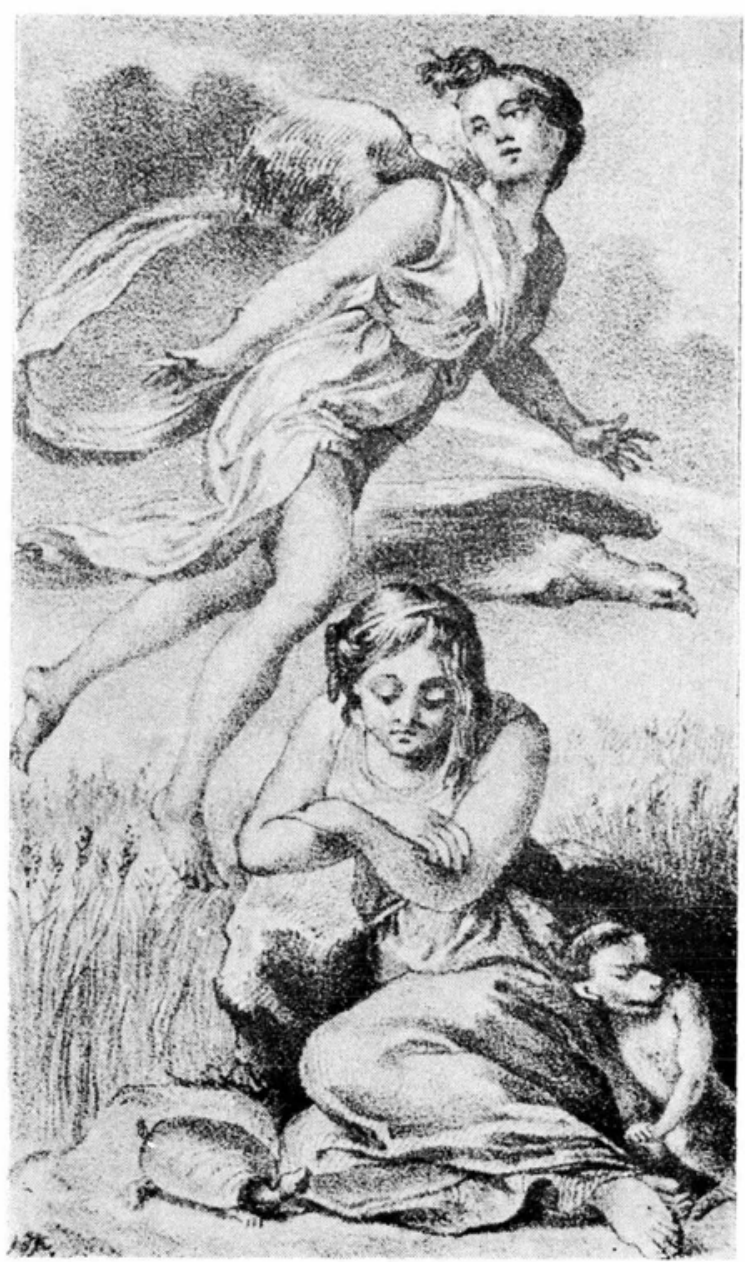




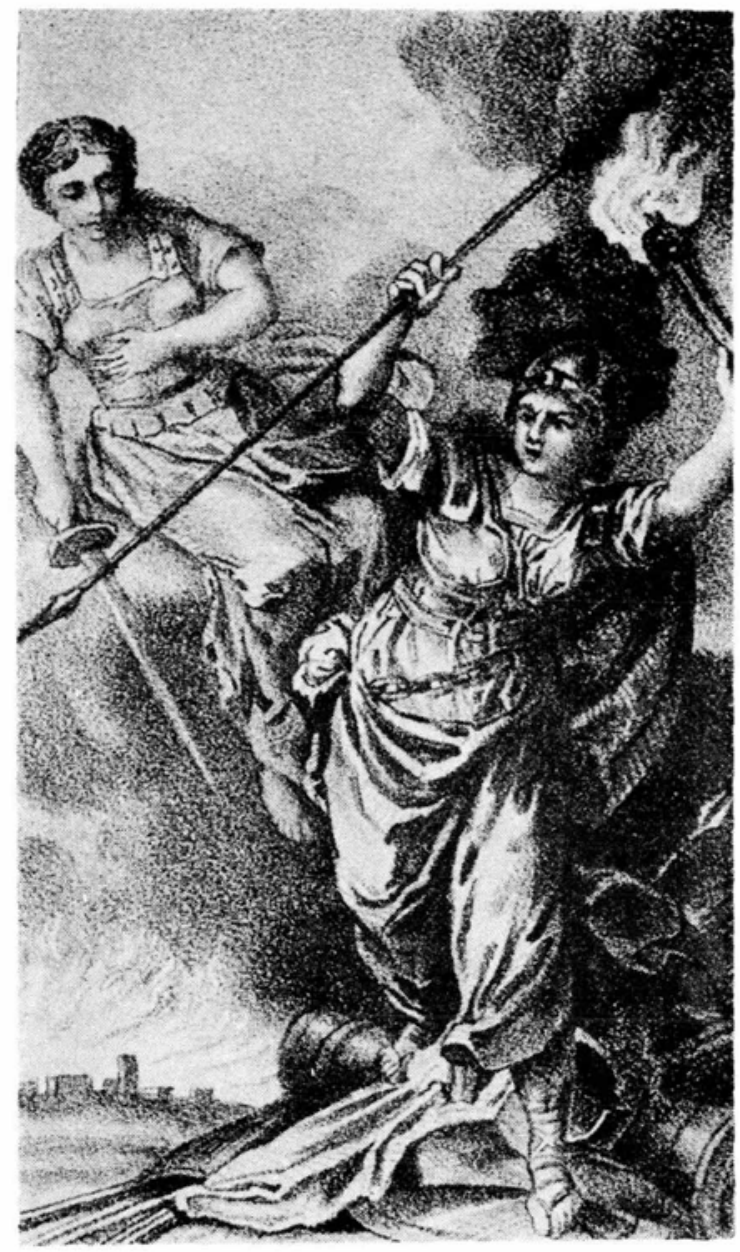

Figura 27. La centelleante figura de Belona significa a la GUERRA; la complementa la también acorazada figura de la Tregua, más tranquila y confiada.
Figura 28. Una composición múltiple bien resuelta, por la clara diferenciación de dos zonas en sentido vertical: arriba, la BENIGNIDAD (o Beneficencia) y la Bondad (con el pelicano); abajo, formando un grupo apretado y convulso, la Maldad (oso), la Perfidia (hidra) y la Malignidad (codorniz).

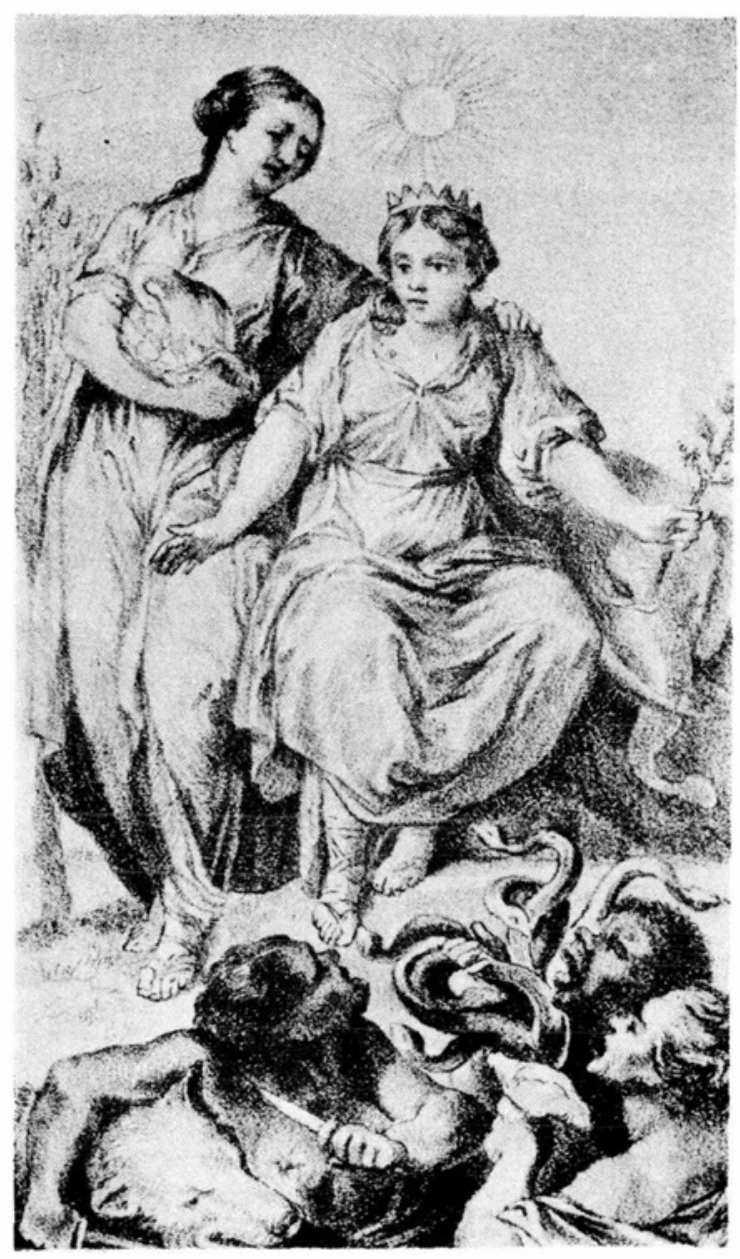




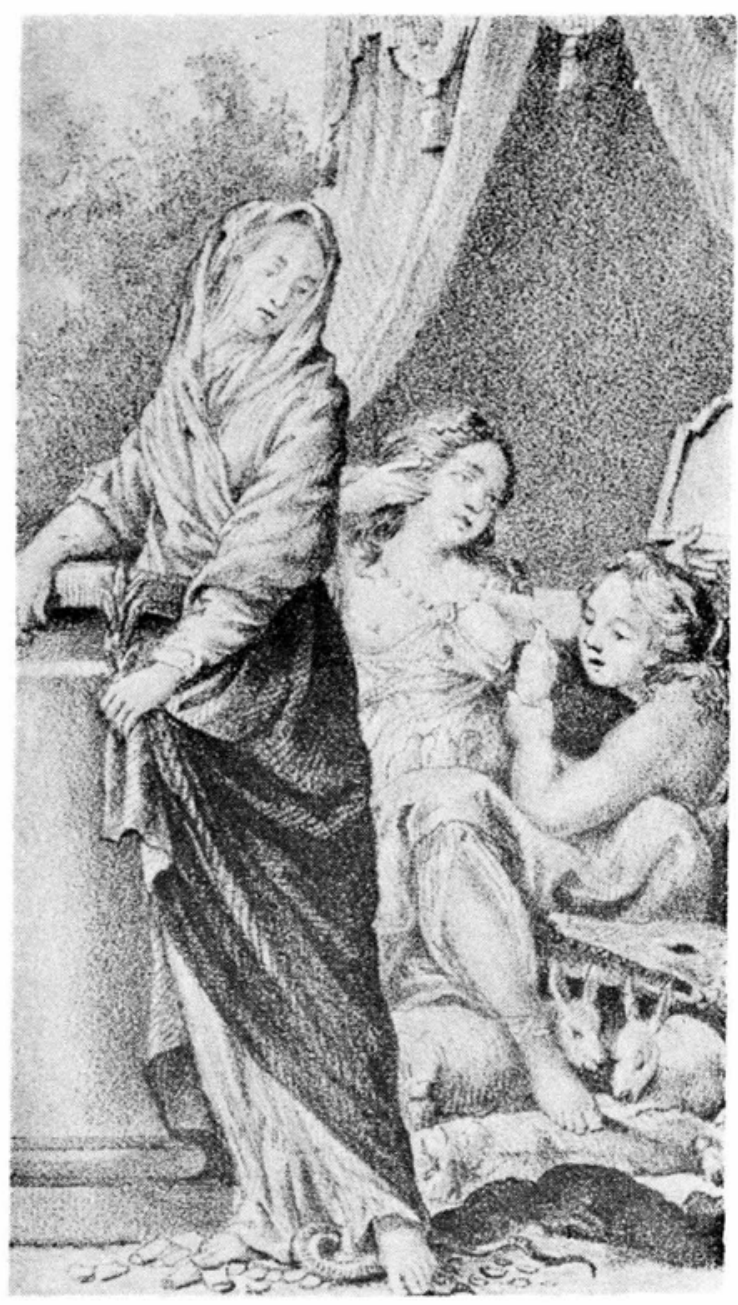

Figura 29. La CASTIDAD (con atributos tomados de Ripa) opone su ademán contenido y su postura vigilante a los de la Lascivia (que se engalana, "recostada voluptuosamente sobre los cojines de la molicie") y la Lujuria (con un cocodrilo, una perdiz y un par de conejos). La composición resulta confusa.
Figura 30. El DESEO alado; los Celos, con sus vestidos bordados de ojos y oídos, y un gallo; la Antipatía, horrorizada a la vista de "esos reptiles a que las mujeres tienen de ordinario más aversión, como los sapos, ratas y arañas": la trivialización de la emblemática.

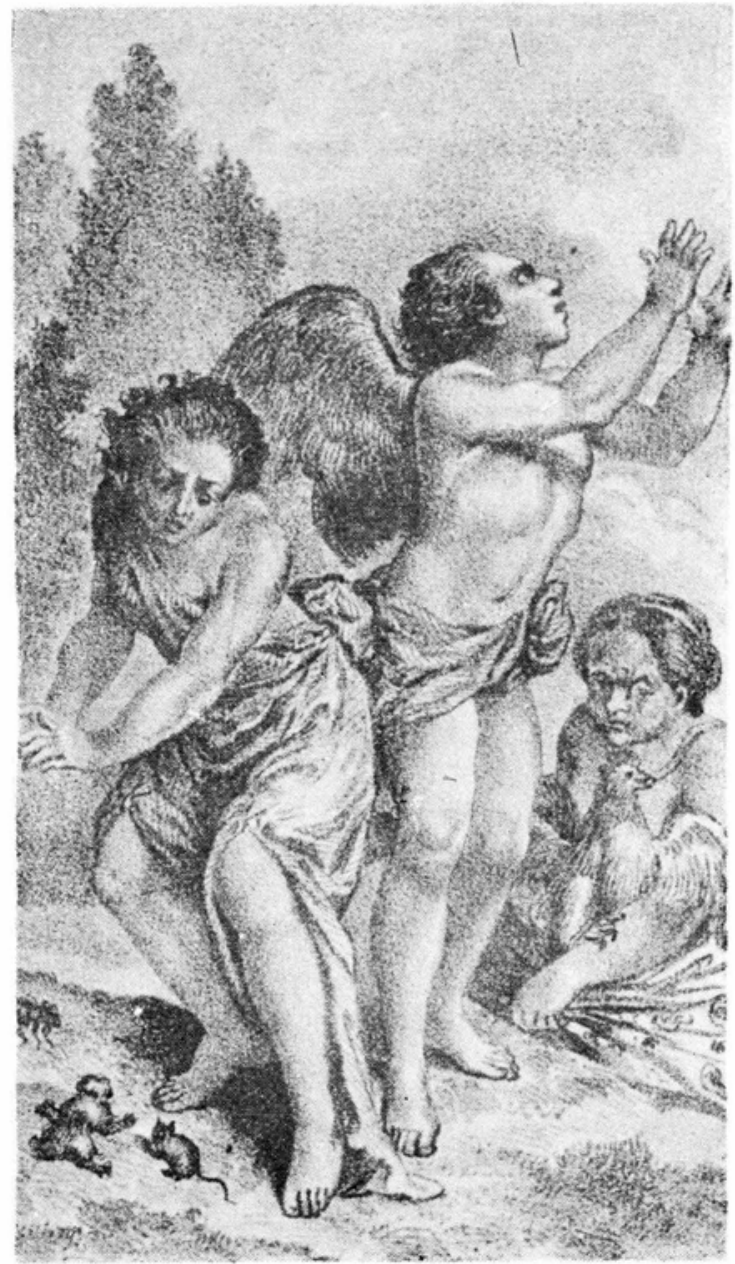


Algunas de estas supresiones son lógicas puesto que las palabras traducidas modifican a veces su primera letra y alfabéticamente les corresponderá un puesto ulterior. Otras estampas parecen haberse suprimido, a mi parecer, porque no se las consideró ya de interés al perder toda validez científica, como podrían ser los temperamentos, asociados a la vieja doctrina de los humores corporales. Alguna supresión sugiere cierta falta de previsión, como la del Agua. Otras, en cambio, son sencillamente absurdas como las de la Danza y el Grabado.

Queda una cuestión importante por comentar: ¿tuvo la obra mexicana continuación?

Ciertamente se publicaron algunas láminas correspondientes al segundo tomo. Conozco cuatro de ellas, en las que figuran la Imaginación, la Indulgencia, la Industria y la Inocencia. En estas estampas el litógrafo tuvo cuidado de variar el enmarcamiento, ahora a base de roleos o formas redondeadas que determinan elegantes figuras. ${ }^{38}$ Pero además de no haber podido localizar todavía ningún ejemplar de este supuesto tomo segundo, hay la circunstancia de que dos acuciosos bibliógrafos, al referirse a la obra, registran la existencia de un solo volumen.

Manuel Toussaint, en La litografia en México en el siglo XIX (1934) da cuenta de la publicación de la Iconclogía, pero no menciona que haya habido dos volúmenes. ${ }^{39}$

Mario Paz incluye la ficha completa del libro en la caudalosa bibliografía iconológica que forma la segunda parte de sus Studies in Sezenteenth-Century Imagery de la siguiente manera: Iconologia o tratado completo de alegorias y emblemas, obra traducida al castellano y ano. tada por el Lic. Don Luis G. Pastor, catedrático de literatura en el Colegio de San Juan de Letrán. Tomo I. México, Emprenta (sic) Económica, 1866. Y añade: Notwithstanding the designation Tomo $I$ the work is complete. ${ }^{40}$

Quede esta cuestión abierta, por el momento, hasta xecabar nuevos datos. Y quede también, para posteriores estudios, precisar la influencia que tuvo este libro sobre los artistas mexicanos, lo que contribuirá sin

38 Las láminas son propiedad de la familia Trejo Campos. Pertenecieron a uno de sus antepasados, Justo Pastor Galván, estudiante y luego maestro en la Academia de San Carlos. Agradezco a la familia Trejo Campos que me ha facilitado las láminas para su estudio.

39 Toussaint, obra citada en nota 34 , p. xxI.

40 Praz, sin embargo, comete un error que juzgo oportuno enmendar, pues consigna el libro de Pastor como una traducción al castellano del de Ripa. 


\section{duda al conocimiento pormenorizado del desarrollo de la iconografía} en la historia del arte de México. ${ }^{41}$

\section{Febrero-marzo de 1980}

$41 \mathrm{El}$ presente artículo fue redactado originalmente (febrero-marzo de 1980) para servir de prólogo a una nueva edición del libro traducido por Pastor, Ia cual, desafortunadamente, no pudo llevarse a buen término. El destino primero del texto explica algunas de sus características, en particular la extensa digresión referente a la génesis y el desarrollo de la Iconología entre los siglos xvr y xvir. He decidido dejarlo tal y como entonces lo redacté, porque no conozco referencias a este problema en la historiografía del arte en nuestro medio.

Durante los largos meses en que la proyectada (y a la postre fallida) reedición del Pastor estuvo en "lista de espera", la doctora Clementina Díaz y de Ovando escribió un breve ensayo sobre la misma obra, al que tituló "Primicias de la Iconología en México (1865)", para ser publicado en un libro de Homenaje al doctor Erwin Palm. En dicho ensayo, la doctora Diaz y de Ovando aporta nueva y muy importante información acerca del traductor mexicano de la Iconologia, el licenciado Luis G. Pastor, y da razones que podemos considerar definitivas para negar la existencia de un segundo volumen de la obra. Dice Díaz y de Ovando:

"A lo ya investigado por (Fausto) Ramírez puede agregarse que Pastor" era de filiación conservadora e imperialista $y$, durante el Segundo Imperio, desempeñó el puesto de secretario del Ayuntamiento de la ciudad de México. Podemos inferir que como una deferencia a un empleado de su administración, el reconocimiento de Maximiliano de Habsburgo se manifestó en elogios y compra de muchas suscripciones, como se lee en el anuncio de 18 de abril de 1866 (en El Cronsita de México), año en que se acabó de publicar la Iconología... Tengo para mí que el segundo tomo de la Iconologia se quedó en el cajón de las buenas intenciones, ya que las circunstancias políticas y económicas por las que atravesaba el Segundo Imperio, es casi seguro que no permitieran a Pastor dar remate a la obra.

A principios del año de 1866, ante la difícil situación financiera del Segundo Imperio, ya nadie abrigaba la esperanza de que pudiexa salvarse... En octubre los imperialistas tuvieton que convencer a Maximiliano de que no abdicase El año de 1867 se inició lúgubre y sin esperanzas. En febrero se embarcó el ejército francés y en abril las tropas republicanas sitiaron la ciudad de Querétaro defendida por las fuerzas imperialistas, sitio que culminó con el fusilamiento del emperador Maximiliano .. "El Segundo Imperio habia dejado de existir .. .

Como secretario del Ayuntamiento, durante los días aciagos del sitio de la ciudad de México por el general republicano Porfirio Dỉaz, Pastor debió ocupar mucho de su tiempo en resolver los problemas inherentes a su cargo: la seguridad, el abastecimiento de viveres, de carbón, de agua.

¿Es posible que dolorida el alma ante el convencimiento del derrumbe del gobierno en el que, como fervoroso imperialista, veía la salvación de México, tuviera Pastor el ánimo para continuar con la traducción de la Iconologia? Creo que entristecido, ayuno de ilusiones, abandonó esa labor...

Más adelante, ... restaurada la República ... insisto, ya no prosiguió la traducción y, si la continuó, no la publicó, pues pensaria que ante la avalancha de novelas, poesías, de obras históricas, de toda esa literatura de carácter nacionalista que estaba apareciendo y que arrebataba a los lectores, la segunda parte de la Iconología no 


\title{
APÉNDICE
}

\section{LISTA DE ESTAMPAS INCLUIDAS EN LA IGONOLOGÍA O TRATADO DE ALEGORIAS Y EMBLEMAS. TOMO I. *}

\author{
1. (Retrato del) Lic. D. Luis G. Pastor \\ 2. (Retrato de H Gravelot) \\ 3. (Retrato de N. Cochin) \\ 4. Iconología o Tratado de Alegorías y Emblemas \\ 5. Astronomía \\ 6. Arte Militar \\ 7. Artes \\ 8. Abril \\ 9. Abundancia \\ 10. América \\ 11. Alegría (y Tedio) \\ 12. Agricultura \\ 13. Abstinencia (y Gula) \\ 14. Afabilidad (y Orgullo) \\ 15. África \\ 16. Afección (Enemistad y Ofensa) \\ 17. Arquitectura \\ 18. Aritmética \\ 19. Aire \\ 20. Apolo \\ 21. Amistad \\ 22. Agosto \\ 23. Asia \\ 24. Botánica \\ 25. Benignidad (Bondad, Maldad, Malignidad y Perfidia) \\ 26. Caridad \\ 27. Caliope
}

encontrara suscriptores interesados, pese a su utilidad para artistas y poetas, a 'la hermosura y elegancia de sus láminas, a los principios de la más sana morẩ; pues là oportunidad de su publicación había pasado."

Agradezco a la doctora Díaz y de Ovando el que me haya permitido citar con amplitud su artículo, estando éste en prensa.

Quiero finalmente dejar constancia de una reciente traducción al castellano de la obra original de Gravelot y Cochin en sus cuatro volúmenes, realizada por María del Carmen Alberú Gómez: "Iconología por Figuras de Graveiot y Cochin. Traducción prolongada y comentada", tesis de licenciatura en Historia del Arte, Universidad Iberoamericana, 1981 .

* Doy en paréntesis información no expresada explícitamente en los títulos que aparecen al calce de las estampas. Asi, por ejemplo, las láminas 2 y 3 no aparecen identificadas en el libro; en las demás sólo se da el nombre de la alegoría principal, pero juzgo de interés consignar el de las figuras subsidiarias representadas con la misma. 
28. Castidad (Lascivia y Lujuria)

29. Celeridad (Lentitud y Pereza)

30. Concordia (Contrariedad y Discordia)

31. Cirugía

32. Clemencia (Perdón, Calumnia y Venganza)

33. Confianza (Desconfianza y Sospecha)

34. Clío

35. Constancia (Perseverancia e Inconstancia)

36. Deseo (Antipatía y Celo)

37. Devoción (Escrúpulo, Hipocresía e Idolatría)

38. Diciembre

39. Dolor

40. Discreción (y Curiosidad)

41. Docilidad (e Indocilidad)

42. Dulzura (Arrogancia y Ferocidad)

43. Economía (y Prodigalidad)

44. Educación (e Ignorancia)

45. Escritura

46. Elocuencia

47. Emulación (Desaliento y Envidia)

48. Equidad (Injusticia e Iniquidad)

49. Erato

50. Esperanza Cristiana

51. Esperanza (y Desesperación)

52. Estio

53. Eternidad (y Tiempo)

54. Estudio

55. Europa

56. Euterpe

57. Experiencia

58. Fecundidad (Fertilidad y Esterilidad)

59. Felicidad (Felicidad Eterna, Felicidad Pasajera e Infortunio)

60. Fuego

61. Febrero

62. $\mathrm{Fe}$

63. Fe conyugal (Lealtad y Traición)

64. Fortuna

65. Fuerza

66. Generosidad (Liberalidad y Avaricia)

67. Genio

68. Geografía

69. Geometría

70. Gloria

71. Gobiemos (Aristocracia, Democracia y Monarquía)

72. Gusto

73. Gracia (y Gracia Divina) 
DOI: http://dx.doi.org/10.22201/iie.18703062e.1983.53.1214

74. Las Gracias

75. Gramática

76. Gratitud (e Ingratitud)

77. Gravedad (y Ligereza de Espiritu)

78. Guerra (y Tregua)

79. Humanidad (Compasión y Crueldad)

80. Humildad (Jactancia, Vanagloria y Vanidad)

81. Invierno 